\title{
The Effect of the Flexibility and Clarification Strategies On Achievement and Improvement of Linguistic Intelligence Skills and Attitudes Towards Arabic Language Subject for Vocational Education Students in Iraq
}

\author{
Rasha Aeada Khalaf \\ Directorate of Education in Anbar, Iraq \\ mila8not@gmail.com
}

\begin{abstract}
KEYWORDS: $\quad$ Flexibility and Clarification Strategies, Achievement, Linguistic Intelligence, Trends.
\end{abstract}
\begin{abstract}
:
The study aimed to identify the impact of the flexibility and clarification strategies on achievement and improvement of linguistic intelligence skills and attitudes towards the Arabic language subject among vocational education students in Iraq. The study adopted the semi-experimental approach, through application on two experimental and control groups of vocational education students in Iraq. The researcher selected two divisions of vocational education students in Iraq: (30) students in the experimental group and (30) students in the control group, so that the educational program was applied to the experimental group, and the control group was taught in the usual way. The educational program, the linguistic intelligence test, and the achievement test were used, and after performing the statistical treatment, the study reached the following results: There are no statistically significant differences at the level of (0.05) in the degree of achievement attributable to the student's gender, where the value of (P) is (1.43), which is not significant. Statistically, there are no statistically significant differences at the level of (0.05) in the degree of achievement due to the interaction between the group and the sex of the student, as the value of $(\mathrm{P})$ reached (2.98) and it is not statistically significant, there are no statistically significant differences at the level of (0.05) In the degree of total linguistic intelligence attributable to the sex of the student, where the value of $(\mathrm{P})$ was (7.09), which is not statistically significant, and there are no statistically significant differences at the level of $(0.05)$ in the degree of total linguistic intelligence due to the interaction between the group and the student's sex, where the value reached $(\mathrm{P})$ (2.93) which is not statistically significant. The study recommended the importance of focusing in the classroom on basic skills in reading and writing, given that these skills have a great role in providing them with the necessary skills that will help them in the future in mastering the skills of reading and writing, and the focus of Arabic language curricula - specifically the lower basic stage - on investigation and storming skills. The teacher's guide included some examples of study plans implemented through investigation and others through brainstorming.
\end{abstract}

\section{REFERENCES:}

Akter, Daisy (2017). Role play in the English language classroom at the tertiary level in Bangladesh. International Journal of English Language Teaching. 5(9).91-99.

Basilaia, G., \& Kvavadze, D. (2020). Transition to Online Education in Schools during a SARS-CoV-2 Corona virus (COVID-19) Pandemic in Georgia. Pedagogical Research, 5(4), em0060. https:// doi.org/10. 29333/pr/ 7937 Retrieved, 27/5/2020.

Draissi, Z. Yong, Q, Z. (2020). COVID-19 Outbreak Response Plan: Implementing Distance Education in Moroccan Universities. School of Education, Shaanxi Normal University. https:// papers. ssrn.com/ sol3/ papers.cfm?abstract_id $=3586783$

Khoon, A. (2005). The Impact of Habits of Mind on Student' Achievement. (on- Line) 47(1) Available; File://www.iproed. com/AR/Paper/sec-Xinmin2.htm- 54k- cached. 
Niemivirta, M. (2008). Habits of mind and academic endeavors: the correlates and consequences of achievement goal orientations. PhD Thesis, Helsinki University, Finland.

Sahu, P. (2020). Closure of Universities Due to Coronavirus Disease (COVID- 19): Impact on Education and Mental Health of Students and Academic Staff. Medical Education and Simulation, Centre for Medical Sciences Education, The University of the West Indies, St. Augustine, TTO.

Yulia, H. (2020). Online Learning to Prevent the Spread of Pandemic Corona Virus in Indonesia. ETERNAL (English Teaching Journal). 11(1) :1-25. 
أثر استراتيجيتي المرونة والتوضيح في التحصيل وتحسين مهارات الذكاء اللغوي والاتجاهات نحو مادة اللغة العربية لدى طلاب التعليم المهني في العراق

\author{
رشا عيادة خلف \\ مديرية تربية محافظة الأنبار، العراق \\ mila8not@gmail.com
}

الكلمات المفتاحية | استراتيجيتي المرونة والتوضيح، التحصيل، الذكاء اللغوي، الاتجاهات.

Crossref doi https://doi.org/10.51345/.v32i4.429.g247

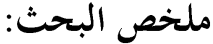

هدفت الدراسة للتعرف على أثر استراتيجيتي المرونة والتوضيح في التحصيل وتحسين مهارات الذكاء اللغوي والاتجاهات نخو مادة

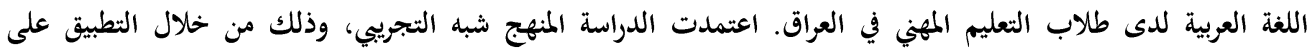

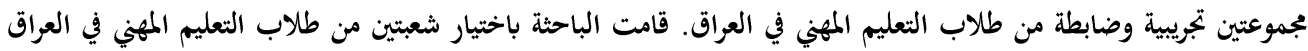

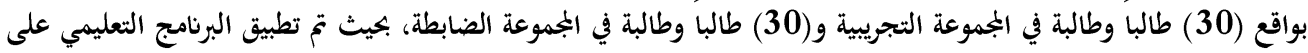

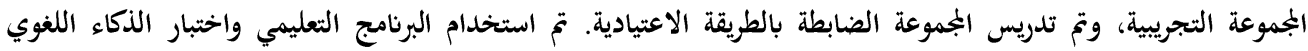

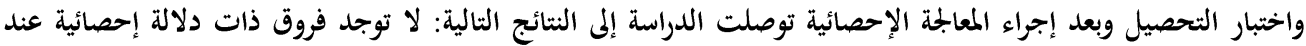

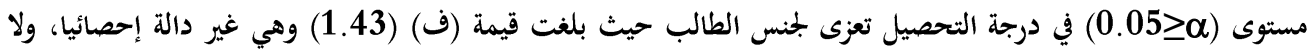

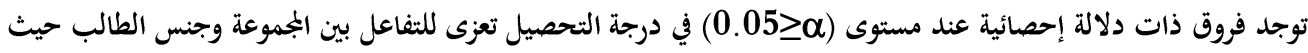

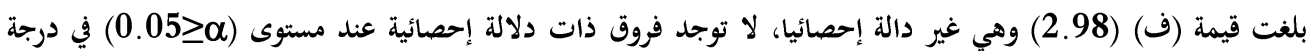

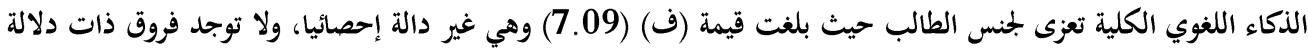

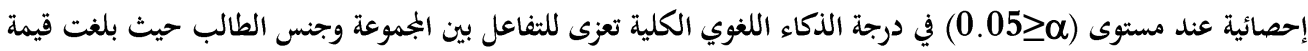

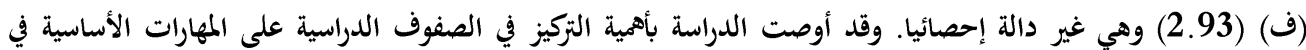

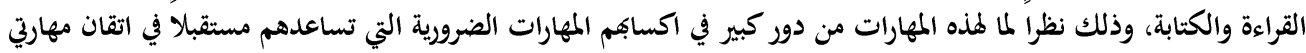

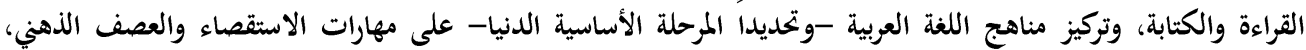

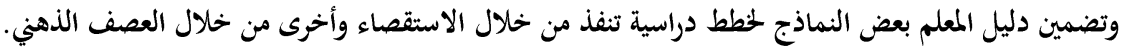


تمثل التربية اليوم حاجة أساسية لإنسان هذا العصر، ووسيلة ضرورية لإشباع حاجاته المعرفية وغير المعرفية،

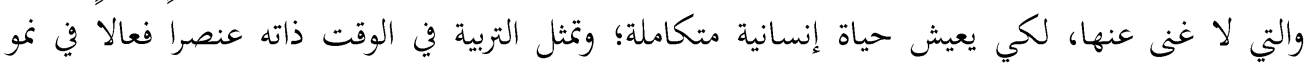

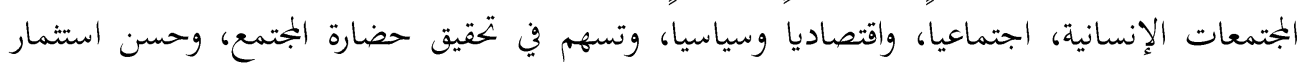
ثرواته البشرية، وتوجيه سلوك أفراده، بما يهقق تقدم الفرد والمجتمع على حد سواء؛ ولذلك فليس من المبالغة

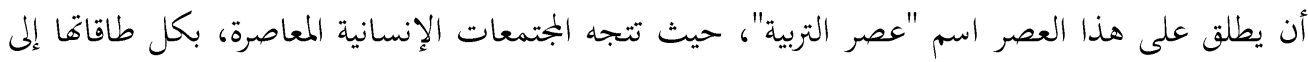

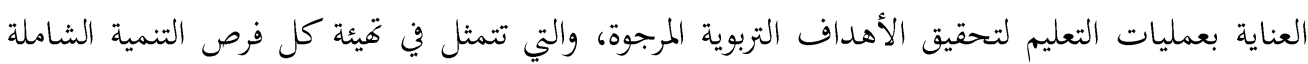
والمتكاملة للأطفال والشباب، في مختلف النواحي الجسمية والعقلية والوجدانية والاجتماعية. وللطاقات البشرية دور مهم في بناء حضارة المجتمعات، وتتم تقوية الجمتمع من خلال بناء الأشخاص ولته

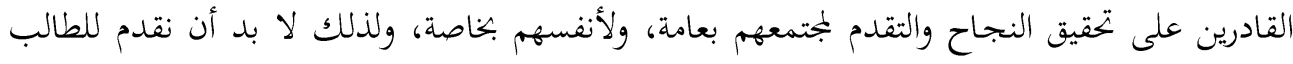

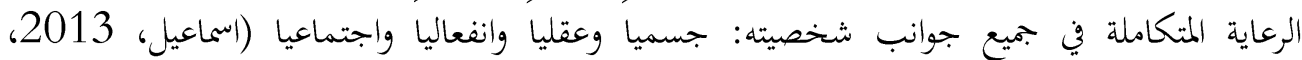

واللغة العربية إحدى لغات العالم الحية، التي تتميز عن غيرها بارتباطها بكتاب الله القرآن الكريم الذي

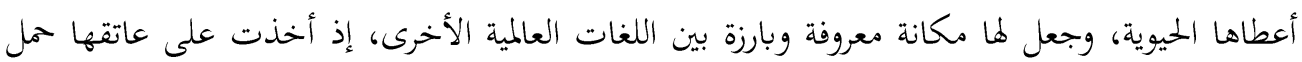

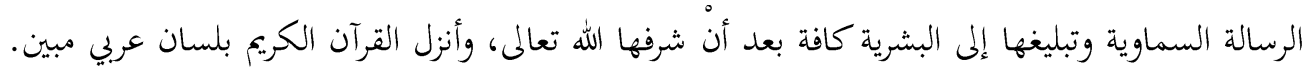

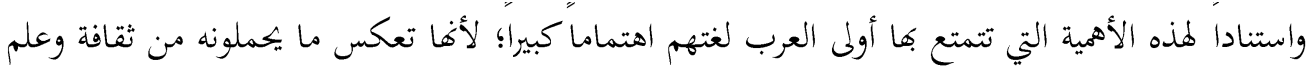
وحضارة، ومن مظاهر اهتمام أبناء اللغة العربية بلغتهم اعتمادها في عملية التعليم والتعلم باعتبارها من المواد الأساسية في المراحل الدراسية كافة ابتداء من المرحلة الأساسية وحتى التعليم الجامعي، إذ أصبحت الأداة الرئيسة لنقل المعلومات والمعارف والعلوم (شبر وجامل وأبو زيد، 2014). الاتجاه (Attitude) في علم النفس يعبر عن الحالة النفسية، وله المكونات والوظائف والخصائص الخاصة به، إذ أنه يعد من أبرز جوانب الشخصية ويصعب تعرفه بشكل دقيق في علم النفس، شأنه في ذلك شأن

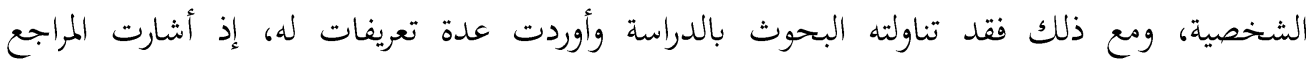
والدراسات التي تناولت الاتحاه إلى أن ظهور مصطلح الاتحاه في علم النفس بدأ مع بداية الأعمال العلمية يف علم النفس التجريبي في الربع الأخير من القرن التاسع عشر، لكن الكلام عنه في ذلك الوقت كان مرتبط

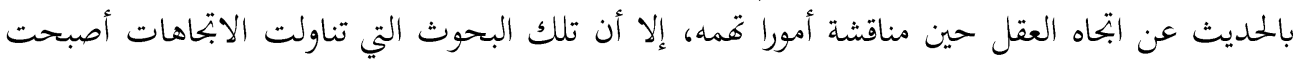
اكثر انتشاراً واتساعاً في الربع الثاني من القرن العشرين. (الزبون، 2020). 


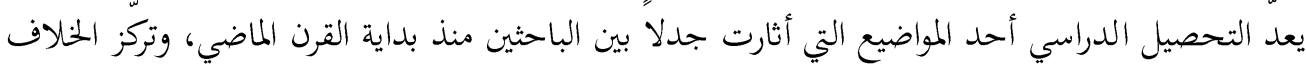

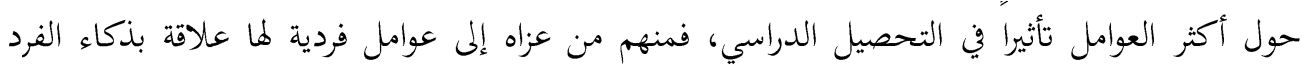

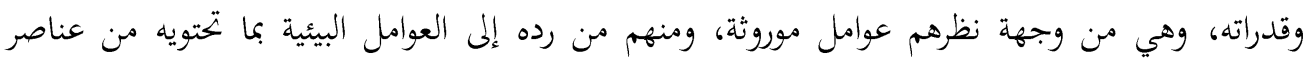

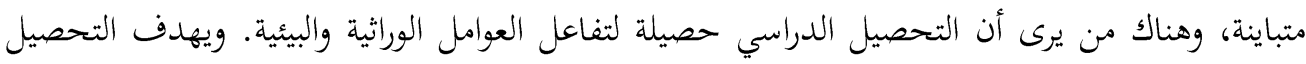

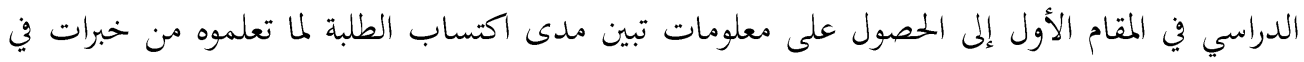

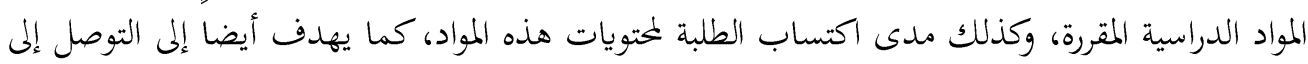

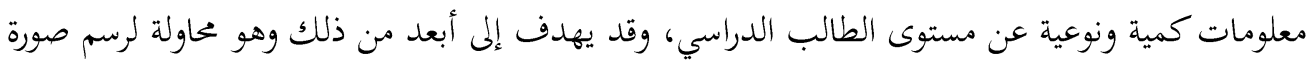

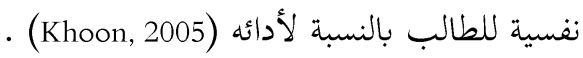

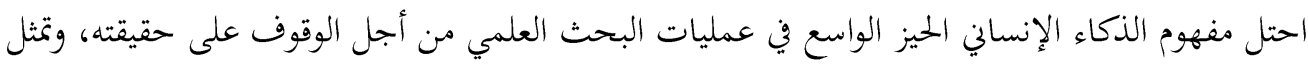

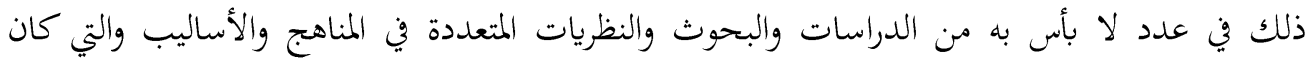

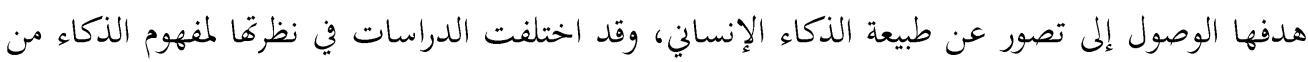
التكوين الأحادي إلى التكوين الثنائي ومن ثم التكوين المتعدد الأبعاد.

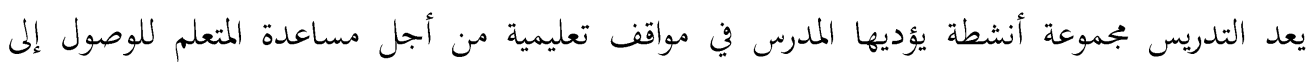

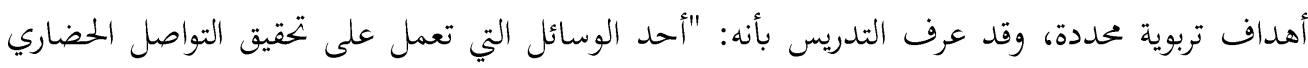

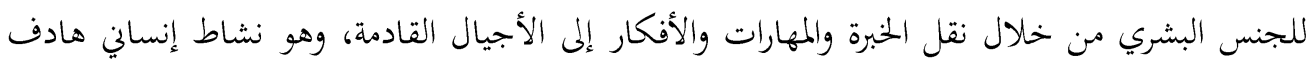

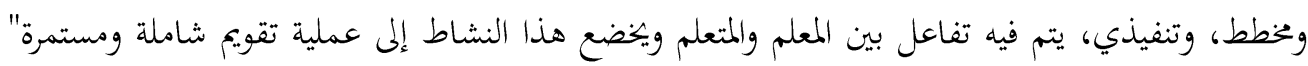

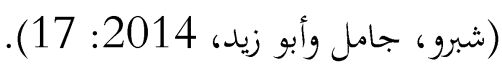
تعتبر استراتيجية المرونة من أهم عوامل مساعدة في نمو التفكير بشكل عامل عام والتكفير الابتكاري بشكل

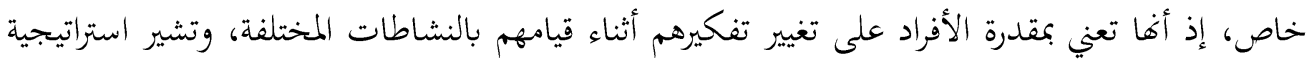

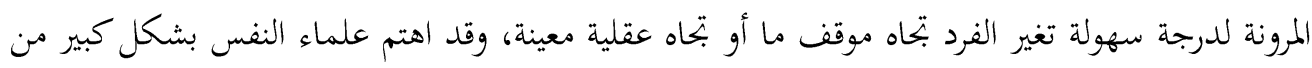

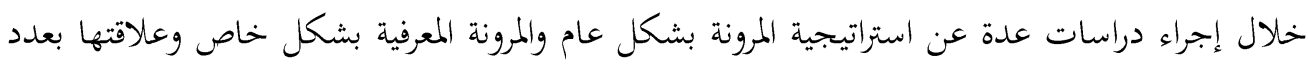

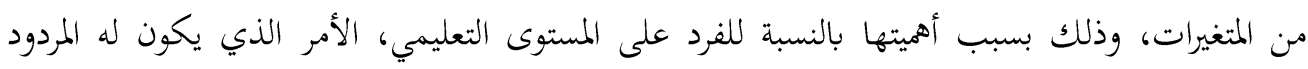

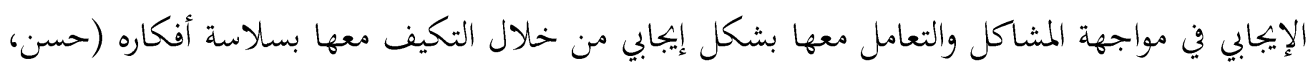

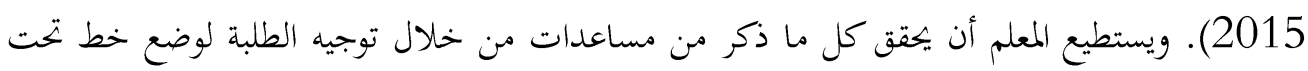

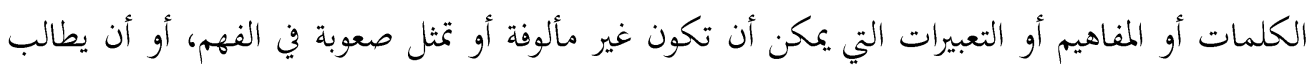


المعلم طلبته بتطبيق إجراءات موضحة أو بعضا منها من أجل التوضيح، والتفكير بصوت مرتفع لتحديد عوائق الفهم وكيفية استخدام الإجراءات التوضيحية (بخش، 2012).

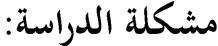

إن عملية التدريس تعد من العمليات التي تحتاج الى توظيف استراتيجيات حديثة وبالرغم من ذلك فإنيان معظم المعلمين يستخدمون الطرق التقليدية في التدريس وعدم استخدام طرق حديثة لتدريس مادة اللغة العربية التي تتصف بالجمود مما يؤثر على عملية التحصيل والاتجاهات نحو مادة اللغة العربية.

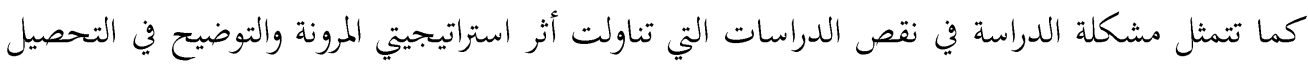

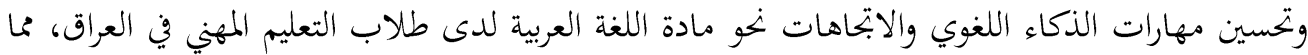
يبرر اجراء مثل هذه الدراسة بما يقدم مساهمة علمية جديدة. وبشكل أكثر تحديدا تتحدد مشكلة الدراسة بالإجابة عن السؤال الرئيسي التالي:

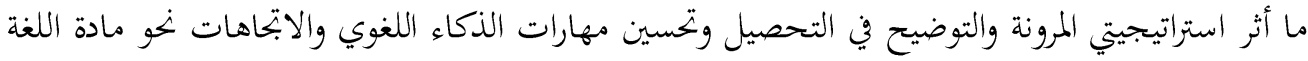
العربية لدى طلاب التعليم المهني في العراق؟ المرنج

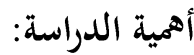

تبرز أهمية الدراسة من كونا تلقي الضوء على أحد الموضوعات التربوية الهامة وهي الاستراتيجيات التدريسية

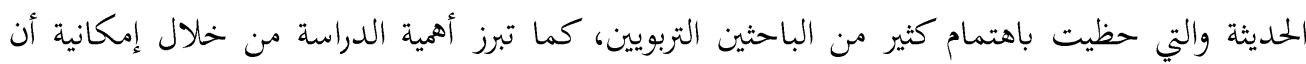

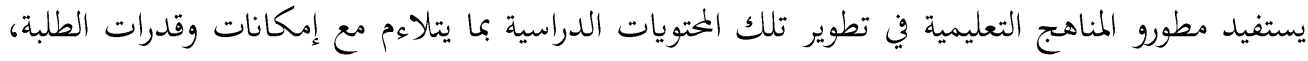
وتوجيه نظر المسؤولين إلى ضرورة تطوير متوى البرامج الإثرائية.

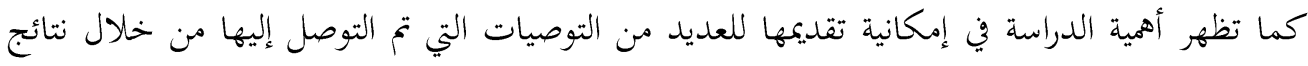

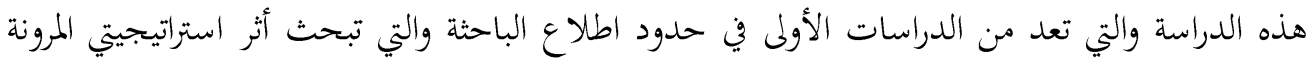

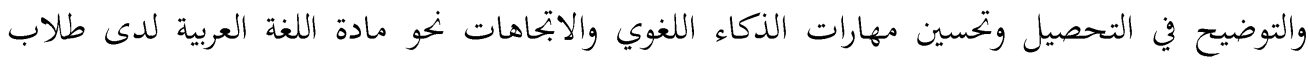
التعليم المهني في العراق مما يشكل إضافة جديدة للمكتبة العربية.

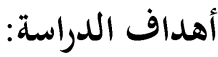

تسعى الدراسة لتحقيق الهدف الرئيسي التالي: بيان أثثر استراتيجيتي المرونة والتوضيح في التحصيل وتحسين

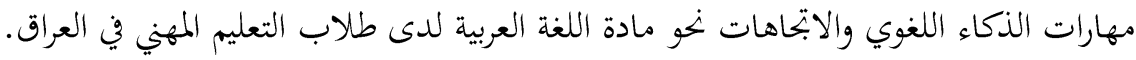
كما تسعى الدراسة الحالية إلى تحقيق الأهداف الآتية: 
- - - بناء برنامج يقيس أثر استراتيجيتي المرونة والتوضيح في التحصيل وتحسين مهارات الذكاء اللغوي والاتحاهات نهو مادة اللغة العربية لدى طلاب التعليم المهني في العراق. - - التعرف إلى أثر استراتيجيتي المرونة والتوضيح في التحصيل وتحسين مهارات الذكاء اللغوي والاتحاهات التهريه نحو مادة اللغة العربية لدى طلاب التعليم المهني في العراق.

\section{اسئلة الدراسة:}

تأتي الدراسة للإجابة عن السؤالين التاليين: 1. لا توجد فروق ذات دلالة إحصائية عند مستوى دلالة (0.05 10 ) بين متوسط علامات أفراد

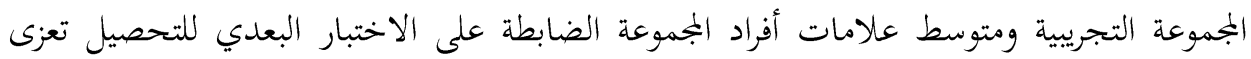
للطريقة (البرنامج التعليمي/ الاعتيادية) والجنس والتفاعل بينهما. 2. لا توجد فروق ذات دلالة إحصائية عند مستوى دلالة (0.05 10 بين متوسط علامات أفراد

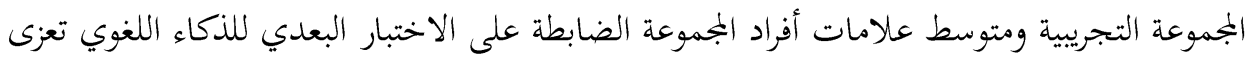
للطريقة (البرنامج التعليمي/ الاعتيادية) والجنس والتفاعل بينهما.

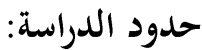

تتمثل حدود الدراسة فيما يلي: - - الحدود البشرية: تقتصر الدراسة على طلاب التعليم المهني في العراق. - الحدود المكانية: تم إجراء الدراسة في المدارس الحكومية في العراق. - الحدود الزمانية: تم تنفيذ الدراسة في العام 2020-2021.

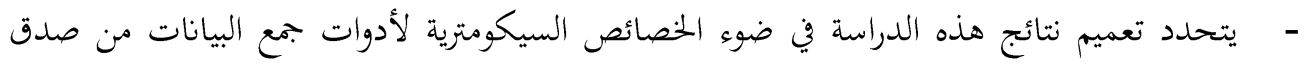
وثبات.

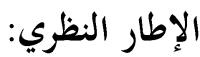

\section{طرائق التدريس}

وجدت عملية التدريس منذ القدم، وما زالت هذه العملية تشهد تطورا ملحوظا في ظل التطور المعرفي والتكنولوجي، مما انعكس على العديد من الموضوعات الهامة في الميدان التربوي ومن ذلك استراتيجيات التدريس على اختلاف أنواعها. 
والتدريس ما هو إلا عملية تواصلية بين الطالب والمعلم، ويتم من خلاله تحقيق النمو العقلي للمتعلم، من خلال التفاعل مع العديد من النشاطات التعليمية، والعلاقات الإنسانية المتبادلة التي تحدث بين المتعلم والمعلم من خلال طرح الآراء للوصول إلى الأهداف المنشودة بحيث يتم إنجاح عملية التعلم، كما يشير إلى

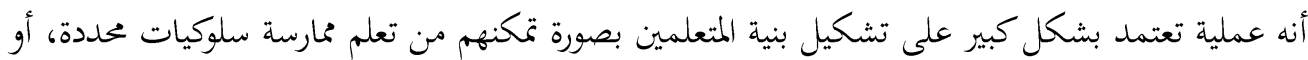

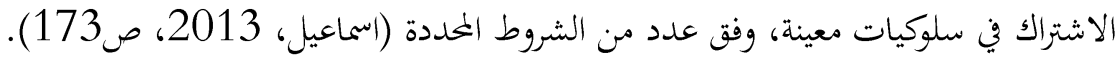

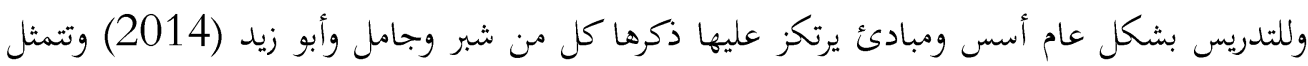
في 1- التعلم يكون أفضل عندما يستخدم المعلمون طرائق تدريس فعاله يتم من خلالها اشتراك المتعلم في العملية التعليمية، وتوظيف خبرات المتعلم القديمة في تدريسه خبرات جديدة وتوظيف أكثر من حاسة اثناء عملية التعلم. 2- تكون عملية تعليم المتعلم أفضل عندما تكون لدى المتعلم رغبة أكيدة في عملية التعلم. 3- ان التعلم يكون أفضل عندما تقدم مادة تعليمية تتناسب واحتياجات وامكانات المتعلم.

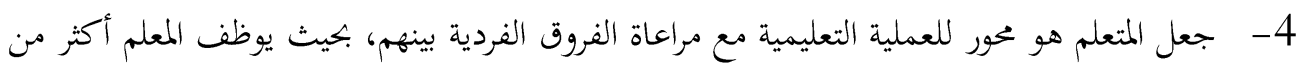

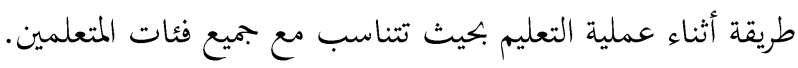
5- الهدف من عملية التعليم هي اكساب المتعلمين معارف وقيم ومهارات تؤهلهم في اكتساب المهارات التعليمية المختلفة في الحاضر والمستقبل. 6- توظيف الوسائل التكنولوجية المتقدمة أثناء عملية التعليم وبشكل مكثف وبميل يضمان يضمن استمرار عملية التعليم. 7- توظيف أكثر من حاسة اثناء عملية التعلم بحيث يتم توظيف المؤثرات والتقنيات المختلفة اثناء هذه العملية.

8- أن تكون أهداف العملية التعليمية واضحة ومحددة بشكل محدد من قبل المعلم وبيان مسار التعلم للمتعلم، والاستفادة من نظريات التعلم وتوظيفها في مواقف تعليمية متعددة. 9- أن تكون ميولات ورغبات الطلبة هي الاساس في تحديد محتوى عملية التعلم مع ضرورة زيادة دافعية الطلبة واثارتم نحو عملية التعلم. 10- أن يكون الهدف من العملية التعليمية هي زيادة استفادة الطالب في مواجهة للمشكلات الحياتية المختلفة بحيث يصبح أكثر عزيمة واصرارا. 
وترى الباحثة أن عملية التدريس لا بد أن تكون عملية مقصودة، وان يتم استثمار جميع الوسائل الممكنة،

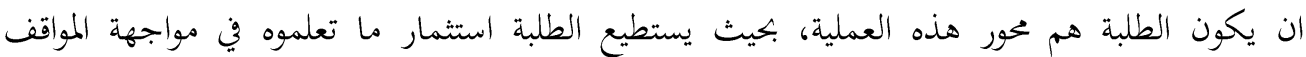
والمشكلات الحياتية المتنوعة.

\section{استراتيجيات التدريس:}

يعد موضوع استراتيجيات التدريس من الموضوعات الهامة والهادفة، والتي نالت اهتماماً واضحاً من قبل المهتمين بالشأن التربوي، حيث بكثوا في العديد من الموضوعات ذات الصلة بهذا المصطلح. وعند استقراء معاجم اللغة العربية نجد ان كلمة استراتيجية ليس لها وجود في هذه المعاجم والقواميس، ولكن هذا المصطلح أصبح شائع الاستخدام شأنه شأن مصطلحات اخرى، وتعد استراتيجيات التدريس مكونا رئيسيا من مكونات العملية التربوية، ويقع على عائق المعلم ان يستثمر هذه الاستراتيجيات بما يحقق النفع والفائدة للمتعلم، ويتوقف عليها نجاح عملية التعلم بشكل عام اذا ما تم توظيفها بالشكل المناسب (عطية، 2006، صن36).

ويعد مصطلح استراتيجيات التدريس من المصطلحات التي دار حولها جدل، وقد يعزى هذا الجدل لأن المصطلح استخدم بشكل موسع، كما أنه مصطلح غير عربي، ويقصد به أنه مصطلح غير عربي، ويقصد به أنه أنه اسلوب هادف واختيار البديل المناسب من بين البدائل والاختبارات المتاحة للمعلم أثناء عملية التعلم

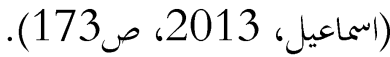
وقد ظهرت عدة تعريفات لهذا المصطلح ومن ذلك أن استراتيجية التدريس تعني:" خطط يوظفها المعلم كي يساعد الطلبة لاكتساب خبرات في أحد الموضوعات بشكل مخطط ومنظم ومتسلل ويتم خلال هذه العملية

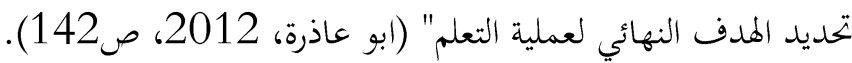
وتعرف استراتيجية التدريس بأغا:" الخطة المنظمة التي يستخدمها المعلم كي يحقق بجموعة اهداف تعليمية، تتضمن طرق وتقنيات واجراءات يتخذها المعلم لتحقيق أهدافا محددة في ضوء ما يتاح له من امكانيات

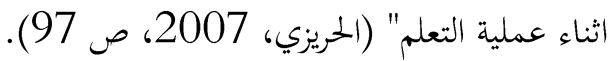
وقد بين جربوع (2014، ص12) ان هناك عدة خصائص لاستراتيجيات التدريس وهي كالآي:

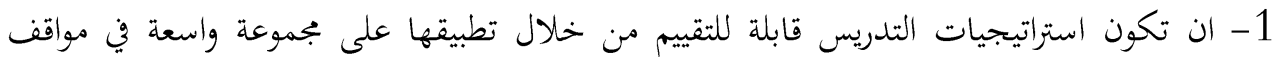
عملية التعلم. 2- مقدرتا على معالجة كمية كبيرة من المعلومات وهو ما يسمى بالمنظور وهو البعد الثاني الذي يوضح القدر الكبير من كفاءة او فاعلية الاستراتيجية المستخدمة في معالجة أكبر كمية من المعلومات. 
3- ارتباطها بشكل مباشر بتسهيل اكتساب المعلومات أو تعلمها اثناء عملية التعلم.

4- توجيه الطلبة وبتهيزهم ومعالجتهم للمعلومات عند المستوى التنفيذي او الاجرائي. 5- ان تكون استراتيجية التدريس قابلة للتعديل في اي مستوى من مستويات عملية التعلم وبما يتناسب لمبك

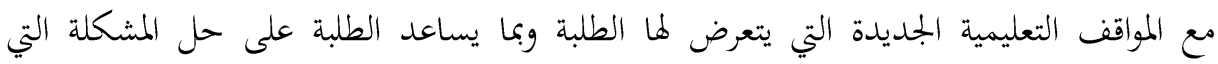
تواجsbم. 6- ان يتم عملية استقبال وتجهيز المعلومات من خلال توظيف أكثر من حاسة اثناء هذه العملية.

\section{الاستراتيجية في التعليم}

شهدت التربية خلال هذا العصر تطورا كبيرا في كل المجالات، في أهدافها وأساليبها وبرابجها، ويؤدي المعلم باعتباره أحد مدخلات النظام التربوي فيه دورا رياديا لقيادة العملية التربوية. وحتى تكون التربية عملية تهتم بالنواحي الجسمية، والعقلية، والاجتماعية، والخلقية والعاطفية، والجمالية كان لا بد من مراعاة قواعد طرائق التدريس، واستيعابها وفهمها؛ لأن هذا يسهل على المعلم مهمته، ويوصله إلى تحقيق الأهداف التعليمية التعلمية بأقل جهد وبسرعة أيضا، ويحقق أغراض الطالب في التعلم والنمو السوي ثانيا.

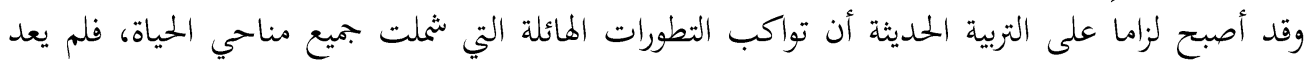

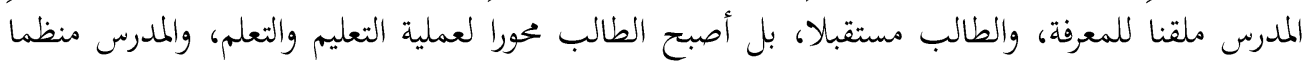

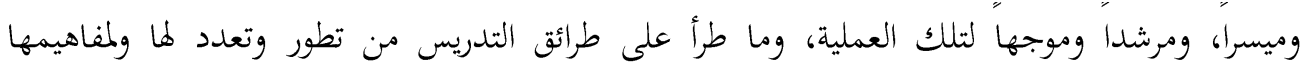

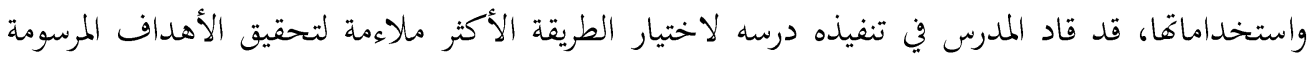
للدرس (موسى وحميد، 2017). إلا أن ضروب النقد المواجهة إلى النزعة التعليمية التلقينية السائدة قد أخذ صوتها يعلو منذ مطلع القرن

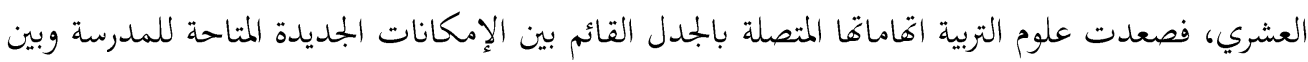
موقف عدم الاكتراث الذي تقف المدرسة حيالها. وتخلق لدى المدرسين ردود فعل ومواقف لا تخلو من قلق

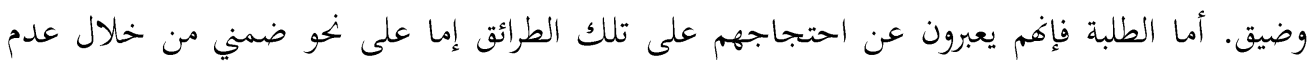
اكتراثهم بالعمل المدرسي، وإما على نحو صريح عن طريق الرفض العلني للمهمات التي يفسرون عليها (عرمش، 2020)

فاستراتيجية التدريس هي في مجملها "بموعة من إجراءات التدريس المختارة سلفاً من قبل المعلم أو مصمم التدريس، يخطط لاستخدامها أثناء تنفيذ التدريس، بما يحقق الأهداف التدريسية المرجوة بأقصى فاعلية

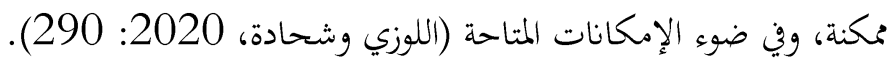


يستخدم مصطلح طريقة التدريس في المؤسسات التربوية، وفي ميادين التربية والتعليم بشكل واسع. ولكنه في الوقت نفسه قد لا يشير إلى معنى محدد في ذهن من يستخدمه "فالمعنى عادة يقترن بخبرة الشخص الذي ميني يستخدم هذا المصطلح، والموقف الذي هو فيه، والمهمة التي يقصدها"(Akter, 2017). ويذكر هوبرت (Hubert) "في هذا المجال بأنه تعدد آراء التربويون حول طرائق التدريس، وتتباين حول ما إذا هونا

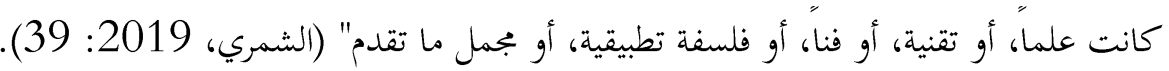

استراتيجيات التدريس

ينظر إلى استراتيجية التدريس على أها مجموعة من الإجراءات المخططة التي يتبعها المعلم داخل الصف الدراسي، أو خارجه لتدريس محتوى موضوع دراسي معين بغية تحقيق أهداف محددة سلفا، وينطوي هذا لئا

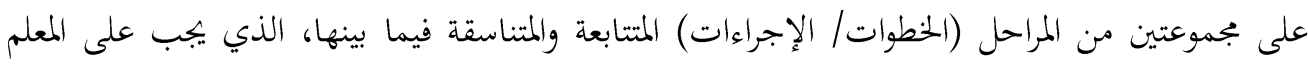

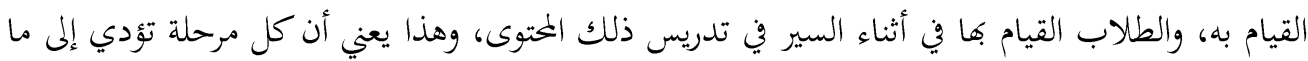
يعدها وتؤثر في المرحلة السابقة والتالي عليها (عرمش، وانس 2020). ترتبط الاستراتيجيات بالأنشطة التعليمية في أفها مخطط له بدقة وتتكون كل استراتيجية من سلسلة محددة

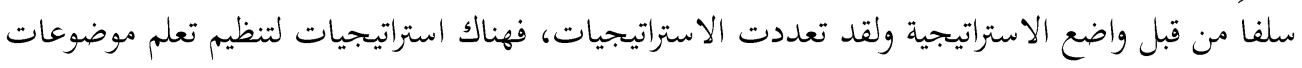

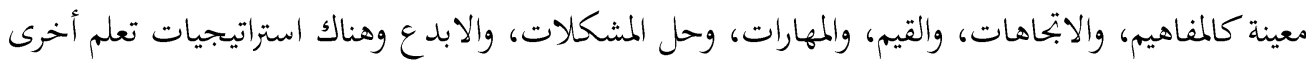
مثل: استراتيجية التعلم الإتقاني، واستراتيجية واستراتيجيات التعليم بالخطوات وغيرها الكثير (الزبون، . $(2020$ إن دور المعلم داخل غرفة الصف ليس مقتصراً على تعليم الطلاب القراءة والكتابة وإنما يتعدى ذلك بكثير

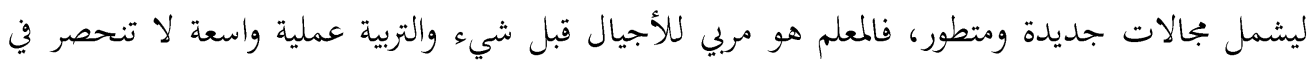
إعطاء الطلاب معلومات وإنما تحدف إلى تنمية الطالب في عقله: وجسمه، وانفعالاته فلذلك نحن اليوبه بحاجة أكثر من قبل إلى استراتيجيات تدريس تمدنا بأفاق تعليمية واسعة، ومتنوعة، ومتقدمة، تساعد طلابنا

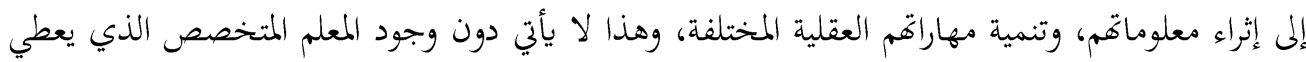
طلابه فرصة المساهمة في وضع التعميمات، وصياغتها وبتربتها، وذلك من خلال تزويدهم بالمصادر المناسبة

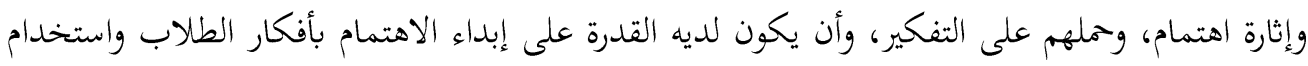

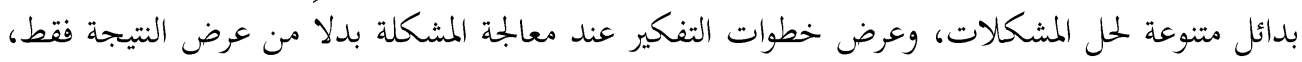
مما يدفعهم نخو تطوير نماذج التفكير، والقدرة على تقييم نتائج التعلم بشكل فعال(سليمان، 2017). 
الاتجاهات والتحصيل الدراسي والذكاء اللغوي

أولاً: الاتجاهات: - (1)

الاتجاه (Attitude) في علم النفس يعبر عن الحالة النفسية، وله المكونات والوظائف والخصائص الخاصة به، إذ أنه يعد من أبرز جوانب الشخصية ويصعب تعرفه بشكل دقيق في علم النفس، شأنه في ذلك شأن الشخصية، ومع ذلك فقد تناولته البحوث بالدراسة وأوردت عدة تعريفات له، إذ أذ أشارت المراجع والدراسات التي تناولت الاتجاه إلى أن ظهور مصطلح الاتحاه في علم النفس بدأ مع بداية الأعمال العلمية ئ علم النفس التجريبي في الربع الأخير من القرن التاسع عشر، لكن الكلام عنه في ذلك الوقت كان مرتبط

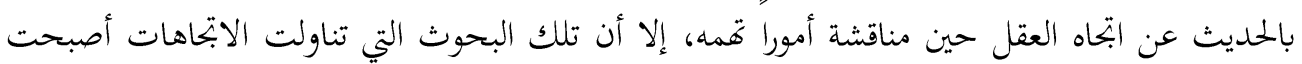

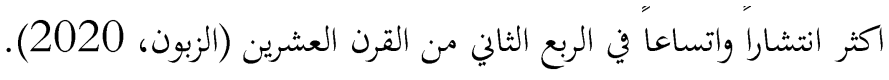

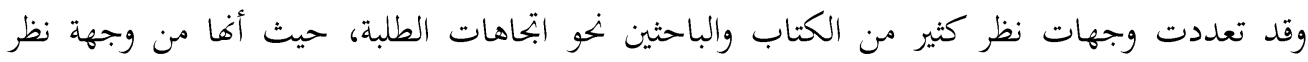

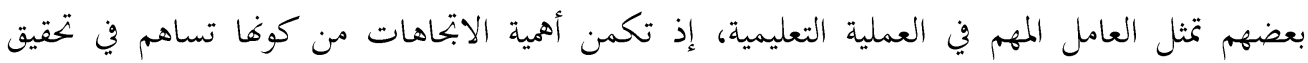
الأهداف، وبناء الخطط، وتنظم خبرة المتعلم وتوجه سلوكه الاجتماعي، والتنبؤ به كما أفها تساهم في إتاحة

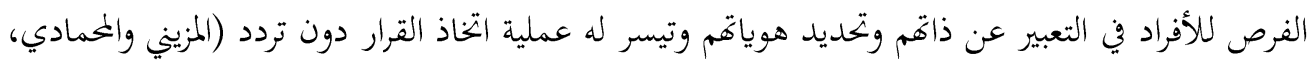

\section{تعريف الاتجاهات:}

يعد مفهوم الاتحاه (Attitude) المحور الأساسي لعلم النفس الاجتماعي، فالفرد يحمل بداخله عددا لا بأس

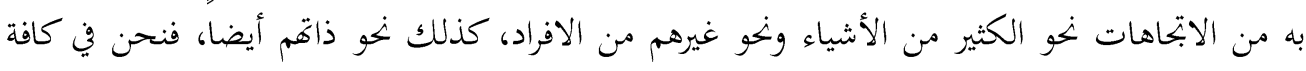
جوانب الحياة الاجتماعية دائماً نسعى في الكشف عن التحاهات الآخرين وإخبارهم عن الأفكار التي

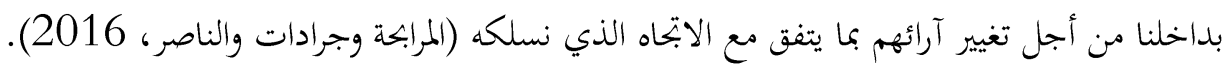

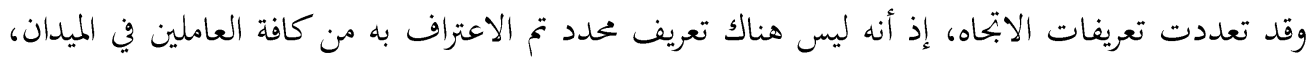

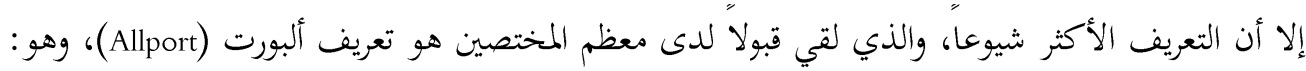

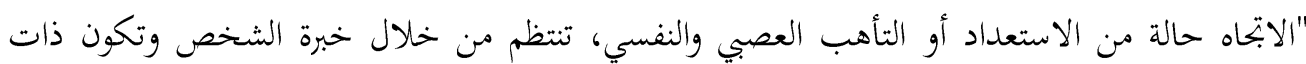
تأثير توجيهي أو دينامي على استجابة الفرد الجميع الموضوعات والمواقف التي تستثيرها هذه الاستجابة"

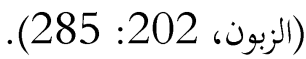




\section{مكونات الاتجاهات:}

أشار جربوع (2014) إلى أن هناك ثلاثة مكونات للاتجاهات هي:

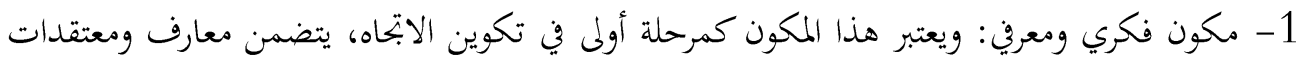
الأفراد بتحاه موضوع معين، ويكتسب من خلال طرق البيئة التي تحيط بالأفراد ودرجة ثقافتهنه

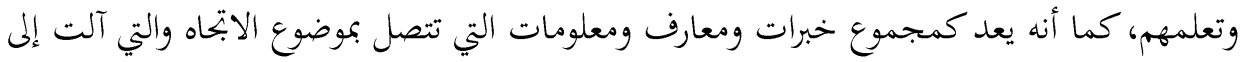

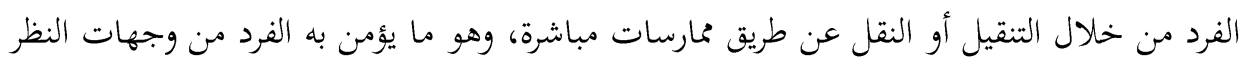

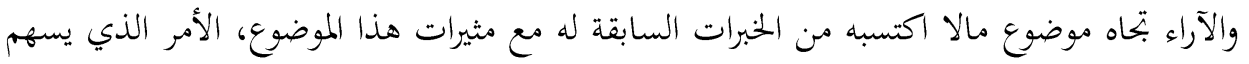
في هيئته وإعداده للاستجابة لما. 2- مكون عاطفي أو وجداني: ويشير هذا المكون إلى مشاعر الكراهية والحب التي في داخل الأفراد نحو

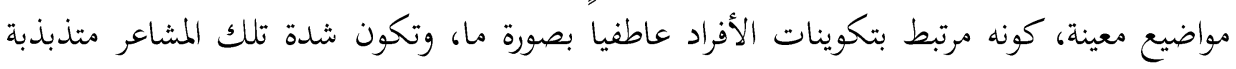
بحسب تقبل الأفراد للموضوع أو رفضه إياه. 3- مكون سلوكي: وهو يعد انعكاس قيم الأفراد واتحاهاتم وتوقعات الآخرين، والطرق الإجرائية المرتبطة

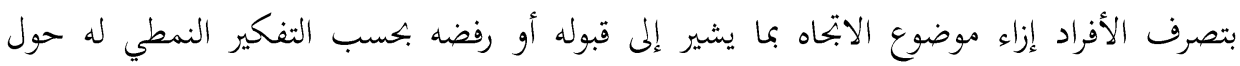

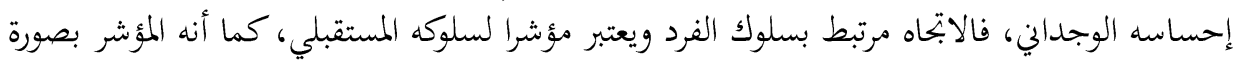
قوية عن سلوك الأفراد الذين لديهم الخبرات المباشرة همدف الاتجاه، ويعبرون عن تلك الاتجاهات بصورة متكررة؛ الأمر الذي يحقق ثبات الاتحاه، فالأفراد يكون سلوكهم معبرا عن إدراكهم لشيء ما هـ ومعرفتهم ومعلوماهم عن ذلك الشيء وعاطفته وانفعاله نحوه، فعندما تتكامل جوانب وأبعاد الإدراك،

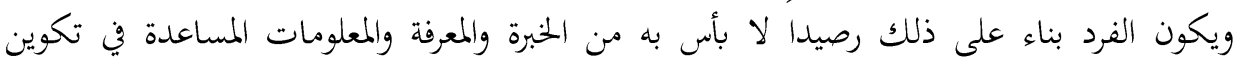
العاطفة أو الانفعال، يقدم الفرد السلوك أو الاستجابة المناسبة مع هذا الانفعال والخببرة والإدراك.

\section{ثانياً: التحصيل الدراسي:}

يشير معظم التربويين بأن مهمة التربية هي الفهم وتعميق التفكير إلا أن نتائج التقرير الإقليمي حول التعليم

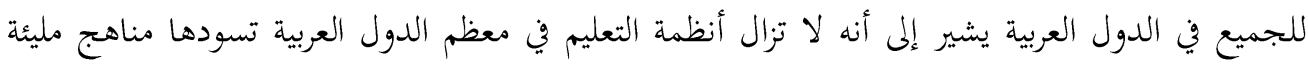
بالحشو والتكرار وطرائق تعلم تقليدية؛ فضلا أن معظم مكوناتها تركز على الحقائق أكثر من المفاهيم والتعميمات والمبادئ مع عدم انسجام المعايير التربوية بشكل عام مع التصميم التكاملي للمنهاج؛ وذلك تصنك لأن تصميم معايير العلوم يقوم على المفاهيم وتصميم معايير الدراسات الاجتماعية بما فيها اللغة العربية يقوم على الحقائق وأن الرياضيات واللغات تقوم على المهارات (Niemivirta, 2008). 
يعد" التحصيل الدراسي أحد المواضيع التي أثارت جدلاً بين الباحثين منذ بداية القرن الماضي، وتركز الحلاف التاف

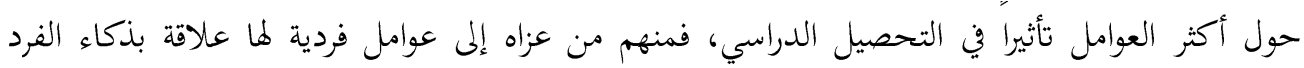

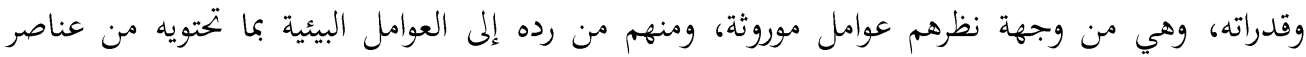

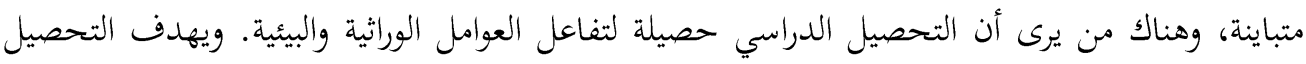

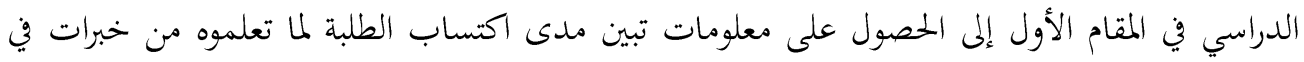

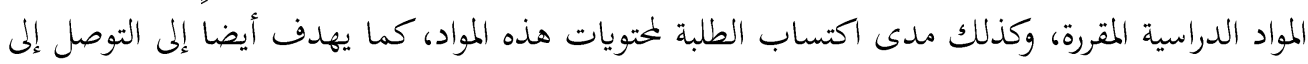

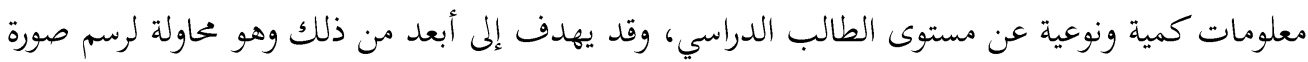
نفسية للطالب بالنسبة لأدائه (Khoon, 2005).

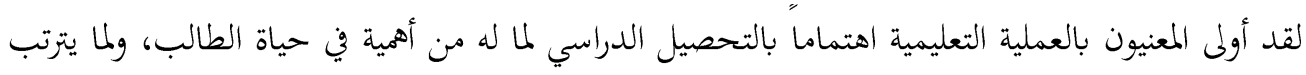

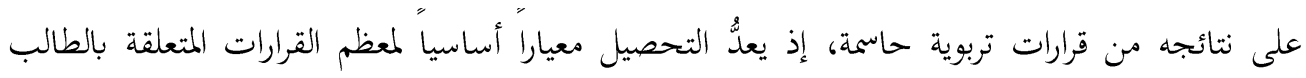

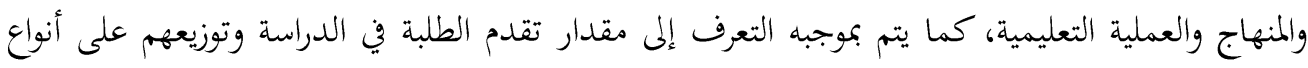

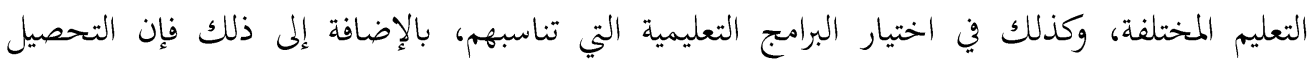

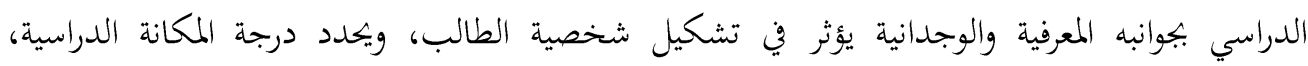
والاجتماعية له (سلمان، وعلوان 2020).

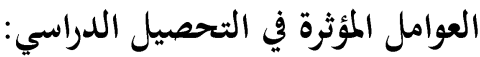

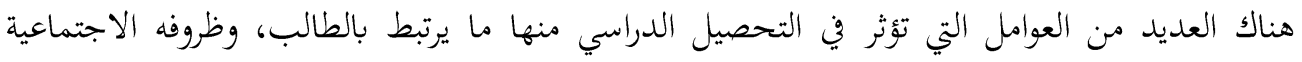

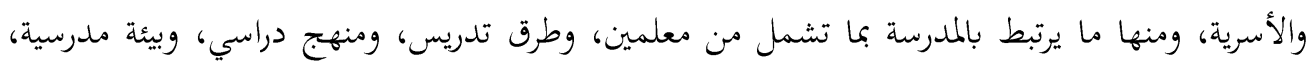
ويمكن إيجاز هذه العوامل فيما يأتي:

\section{أولاً: عوامل ذاتية متعلقة بالطالب:}

تشمل الجوانب الصحية للطالب من الناحية العضوية والنفسية، مستوى قدراته العقلية، والميول

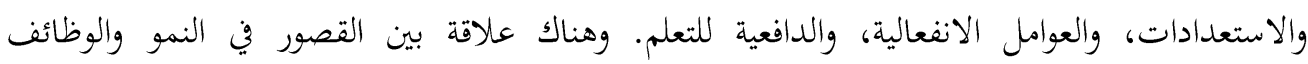

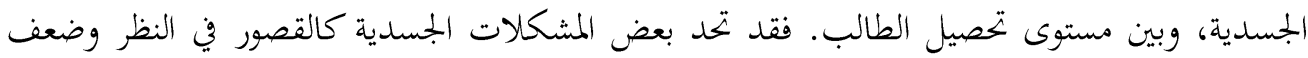

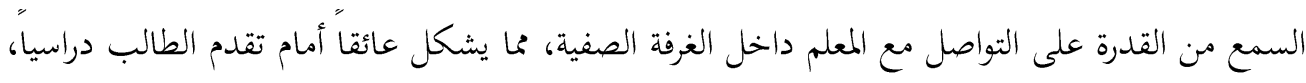
وبالتالي تدني مستوى التحصيل الدراسي لديه (اللوزي وشحادة، فواز 2020). 


\section{ثانيا: عوامل أسرية اجتماعية واقتصادية:}

يعد الجانب الأسري والأجواء التي تسود المنزل من أهم العوامل التي تؤثر على تركيز الأبناء، وعلى التحصيل

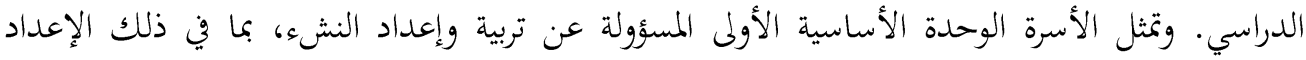

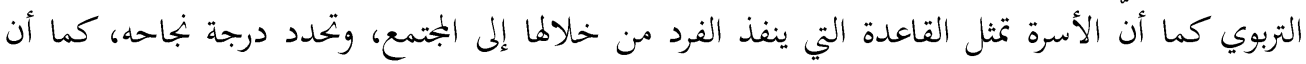

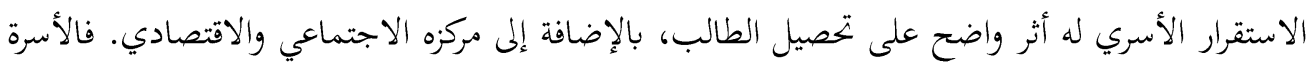

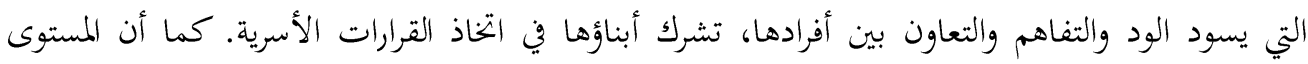
الاقتصادي للأسرة، يؤثر في تقدم الطالب الدراسي، فالأسرة التي يشيع فيها الحرمان الثقافي والجهال؛ لا تعير الاهتمام الكافي لأبنائها، أما الأسر ذات المستوى الاقتصادي الجيد فإِها توفر لأبنائها ما يحتاجون إليه.

\section{ثالثا: عوامل بيئية مدرسية:}

تمثل المدرسة واحدا من أهم العوامل المؤثرة في التحصيل الدراسي. فالمدرسة كنظام اجتماعي وتربوي؛ تشمل العديد من العوامل التي تئثر على التحصيل، والتي من أهمها المعلم، والمنهج، والجو الدراسي.

المعلم:

يعد" المعلم ركنا أساسياً في العملية التعليمية ابتداء من دوره الفاعل في المدرسة بتوفير بيئة ومناخ دراسي مناسب للطالب، ولا يمكن أن ينجح ذلك إلا بوجود معلم كفؤ، يمتلك القدرات والصفات التي تؤهله للقيام بدوره التربوي الفاعل، وتشمل الإعداد الجيد، الذي يمكنه من السيطرة على المادة العلمية، والإعداد التربوي الذي يؤهله لتطبيق استراتيجيات التعليم الفاعلة (الزبون، 2020) وملما بمهارات تعليم التفكير التهي

$$
\begin{aligned}
& \text { وأهمها: } \\
& \text { 1- يخطط للموقف التعليمي. } \\
& \text { 2- يهيئ جوا تعليميا مناسبا. } \\
& \text { 3- يتبنى نظرة ايجابية نهو المتعلم. }
\end{aligned}
$$

4- يظهر ميلا ايجابيا وماسيا للمواقف التي تثير التساؤل والتفكير. 5- يؤمن بأن التفكير مهارة تتقوى وتزداد بالتدريب المنظم. 6- يحترم تفكير الطلبة مراعيا مراحلهم النمائية. 7- 


\section{المنهج الدراسي:}

لا تقل أهمية المنهج الدراسي عن أهمية المعلم، بل أنّ ما يقوم به المعلم يرتبط بما يحتويه المنهج الدراسي، ومن هذا المنطلق فإن طبيعة المنهج الدراسي من العوامل الأساسية التي تسهم في رفع كفاءة الطالب الدراسية.

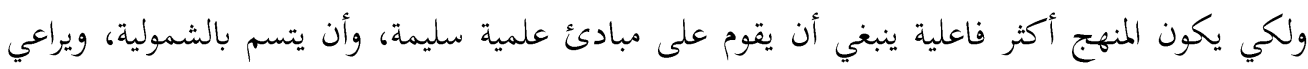
الفروق الفردية.

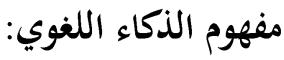

يعد الذكاء اللغوي إحدى الأشكال الراقية للنشاط الإنساني، فقد أصبح في الوقت الحالي مشكلة من

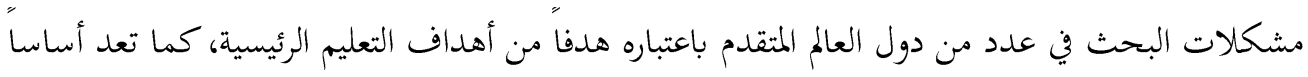
لبناء الحضارات وإنتاج العقول المبدعة، ولذلك أصبحت تنمية الإمكانات البشرية والمهارات الفكرية ضرورة للتوافق مع التطورات التكنولوجية والمعرفية المتلاحقة التي يواجهها الإنسان، ويفرض ذلك على العملية

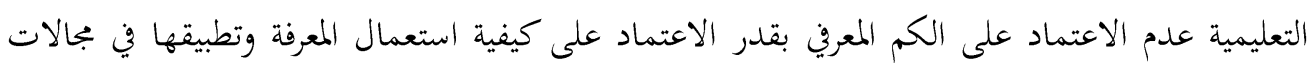
الحياة المختلفة، كما أن تعدد الذكاء واختلافه لدى الفرد يتطلب إتباع مداخل تعليمية - تعلمية متنوعة

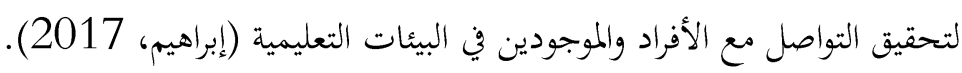

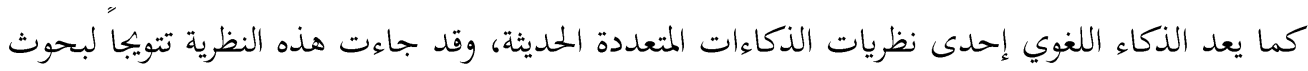

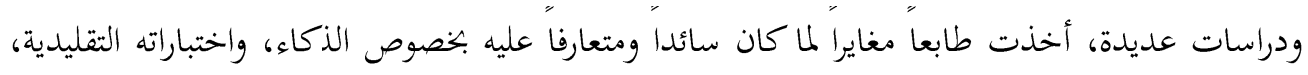
وملبية في الوقت نفسه الحاجات التعليمية الراهنة، ومساعدة الفرد على اكتشاف نفسه والتعبير عن قدراته وإمكاناته، وتطلعاته المستقبلية، ورسم خطط النجاح على الأصعدة كافة وليس على الصعيد الأكاديمي فقط (جابر، 2019)

\section{الانعكاسات التربوية لتطبيق الذكاء اللغوي في الغرفة الصفية:}

أظهر تطبيق الذكاء اللغوي الإيجابي الآتي (بخش،2012):

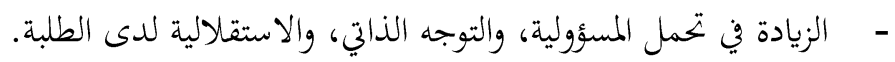
- الانخفاض في مشكلات النظام المدرسي بدرجة ملحوظة. - - التمكن من تطوير مهارات جديدة، وتطبيقها. - ت تحسن مهارات التعلم التعاوين. 


\section{الاستراتيجيات الحديثة (المرونة، الإيضاح)}

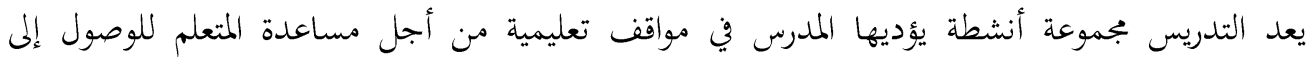

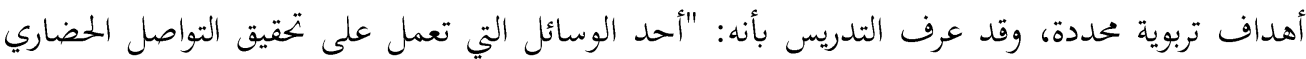

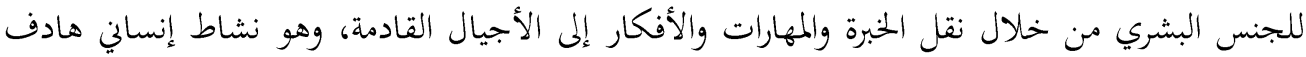

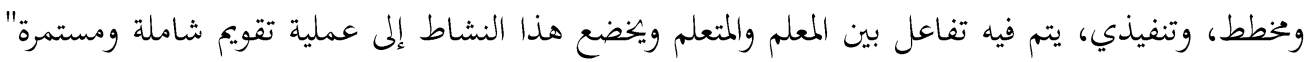

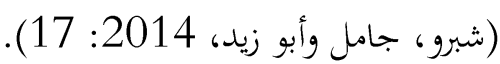
وعليه، فعملية التدريس عملية مهمة تتبعها المدرسة من أجل تنشئة الأجيال الجديدة، لذلك فإن هذه العملية لا تأتي عشوائية ولكن تكون منظمة وهادئة. وقد أشار إسماعيل (2014) من أبرز المفاهيم التي دار حولها الجدل وذلك بسبب كثرة استخدام هذا المفهوم، فالاستراتيجية كلمة غير عربية يقصد بها أسلوب هادف واختيار بديل أمثل من بين البدائل والاختبارات المتاحة.

\section{أولاً: استراتيجية المرونة:}

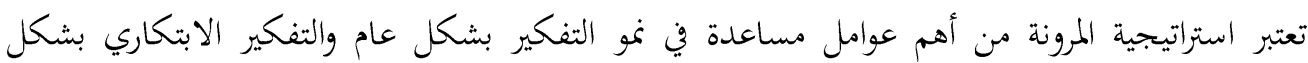

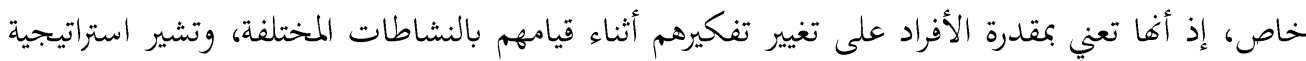

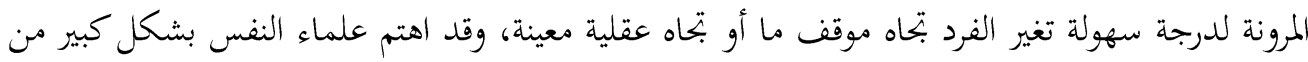

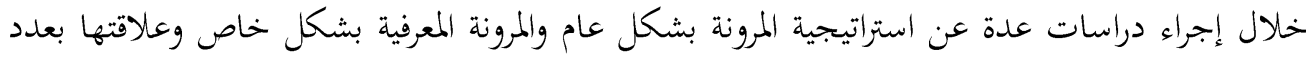

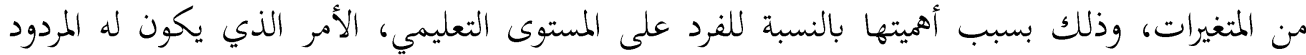

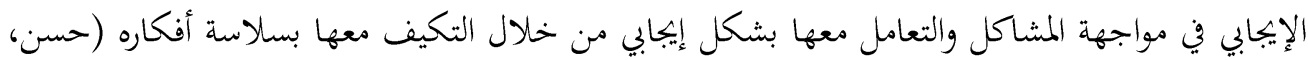

وتعد استراتيجية المرونة من الأبعاد الشخصية الإنسانية المهمة، وتعني المثابرة لاكتساب الأنماط السلوكية

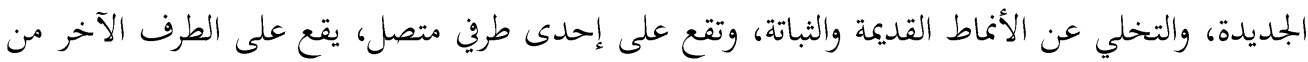

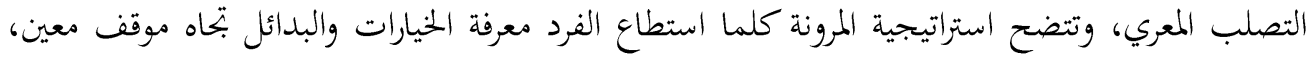

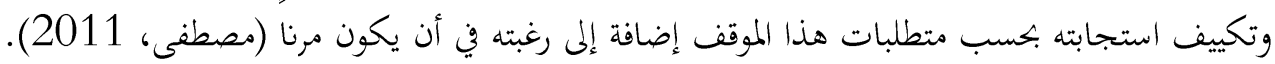




\section{ثانيا: استراتيجية التوضيح:}

عند انشغال القارئ في توضيح النص، وذلك بتحديد نقط الصعوبة فيه سواء من مصطلحات أم مفاهيم أم تعبيرات، فإن هذا لإجراء يوجهه لاستراتيجية بديلة من أجل التغلب على تلك الصعوبات، إما بإعادة

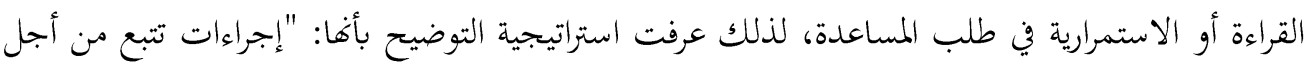

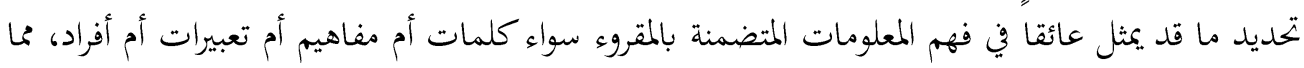
يساعد القارئ على اكتشاف قدرة الكاتب على استخدام الألفاظ والأساليب في التعبير عن المعاني والاستعانة بمساعدات من داخل القطعة أو خارجها للتغلب على هذه الصعوبات من مثل: نطق الكلمات

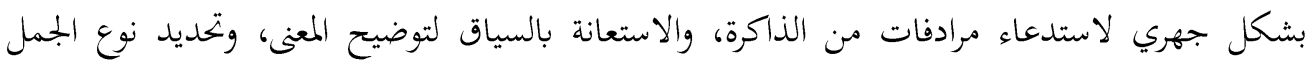
والعبارات أهي استفهامية أم خبرية، والاستعانة بعلامات الترقيم لتوضيح العلاقات بين الكلمات والجمل

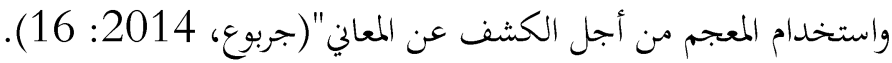

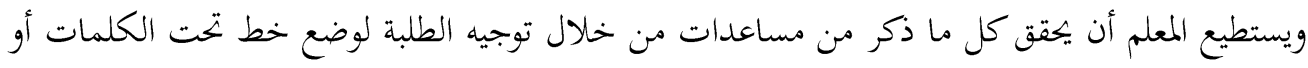
المفاهيم أو التعبيرات التي يمكن أن تكون غير مألوفة أو تتثل صعوبة في الفهم، أو أن يطالب المعلم طلبته بتطبيق إجراءات موضحة أو بعضا منها من أجل التوضيح، والتفكير بصوت مرتفع لتحديد عوائق الفهم وكيفية استخدام الإجراءات التوضيحية (بخش، 2012).

ثانياً: الدراسات السابقة فيما يلي عرض للدراسات السابقة ذات الصلة:

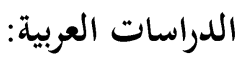

دراسة سلمان وعلوان (2020) بعنوان: أثر استعمال استراتيجية سوم في تحصيل مادة قواعد اللغة العربية لدى طلبة قسم التربية الحاصة. هدفت هذه الدراسة الكشف عن أثر استراتيجية سوم في تحصيل طالبات التربية الخاصة في مادة قواعد اللغة

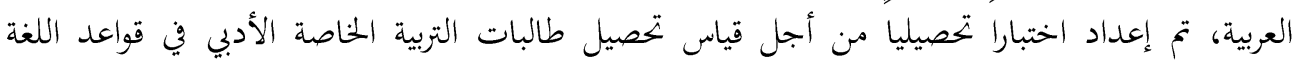

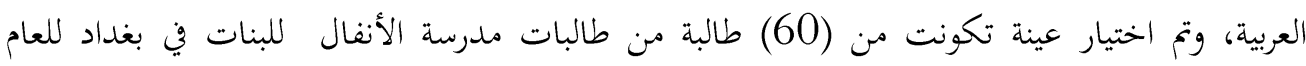

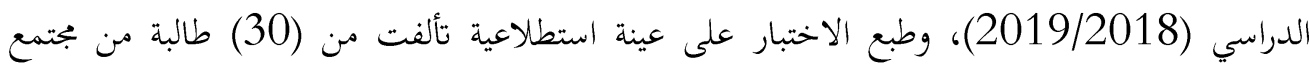
الدراسة، تم التوصل لعدد من النتائج من أهمها: أن تفوق طالبات المجموعة التجريية اللواتي درسن باستراتيجية سوم على المجموعة الضابطة اللواتي درسن بالطريقة التقليدية في تحصيل طالبات التربية الخاصة 
ين مادة القواعد في اللغة العربية، وفي ضوء النتائج أوصت الدراسة بضرورة دراسة أثر استراتيجية سوم في تدريس مادة اللغة العربية في متغيرات تابعة أخرى كالاتحاه نحو المادة - الدافعية - الاحتفاظ- الذكاء الحركي.

دراسة الزبون (2020). بعنوان: أثر استراتيجية الصف المقلوب في تحسين مستوى الدافعية والتحصيل الدراسي لدى التلاميذ بطيئي التعلم في الرياضيات. هدفت الدراسة إلى الكشف عن أثر استراتيجية الصف المقلوب في تحسين مستوى الدافعية والتحصيل الدراسي لدى التلاميذ ذوي بطئ التعلم في مادة الرياضيات، تم اعداد اختبار للرياضيات ومقياس للدافعية لعينة تكونت من (30) تلميذا من ذوي بطئ التعلم قسموا ضمن مجموعتين: بتريبية وضابطة، وأظهرت النتائج أن هناك فروقا ذات دلالة إحصائية عند مستوى بين المتوسطات الحسابية في أداء بجموعتي الدراسة ين تحسن مستوى الدافعية والتحصيل الدراسي للتلاميذ ذوي بطئ التعلم في مادة الرياضيات في القياس البعدي تعزى لمتغير استراتيجية التدريس ولصالح المجموعة التجريبة، وأوصت الدراسة بضرورة تطبيق استراتيجية الصف المقلوب من أجل تحسين مستوى الدافعية وتحصيل التلاميذ ذوي بطئ التعلم في الرياضيات الدراسي. دراسة الثبيتي (2020) بعنوان: واقع استخدام معلمات اللغة العبية في مرحلة التعليم الثانوي في مدينة الطائف لاستراتيجيات التعلم النشط. هدفت الدراسة التعرف على واقع استخدام معلمات اللغة العربية في مرحلة التعليم الثانوي في مدينة الطائف لاستراتيجيات التعلم النشط، تم تطبيق أداتي الملاحظة والاستبانة على عينة تكونت من (23) معلمة في اللغة العربية في مدارس ثانوية حكومية، واستخدم اختبار (ت) لعينة واحدة واختبار مان ويتني من من منيك أجل تحليل بيانات الدراسة، وتوصلت الدراسة إلى أن درجة استخدام معلمات اللغة العربية في المرحلة الثانوية لاستراتيجيات التعلم النشط جاءت متدنية، وأن دور المشرفة التربوية في تعزيز معلمات اللغة العربية يف المرحلة الثانوية لاستخدام استراتيجية التعلم النشط جاءت متوسطة، كما أن الصعوبات التي تواجه معلمات اللغة العربية في استخدام استراتيجيات التعلم النشط كانت كبيرة. كما أن هناك عدم وجود فروق ذات دلالة إحصائية في استخدام المعلمات لاستراتيجيات التعلم النشط تعزى لمتغيرات الدراسة عدا متغير سنوات الخبرة، وكانت الفروق لصالح المعلمات ذوات الخبرة الأكثر من 10 سنوات. 
دراسة الزبون (2020) بعنوان: اتجاهات طلبة المرحلة الأساسية في الممارس الحكومية في عمان نحو استراتيجية لعب الأدوار في مادة اللغة العربية.

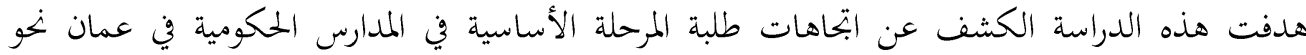

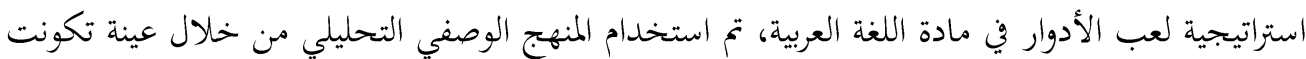

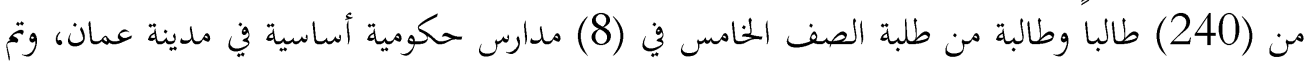

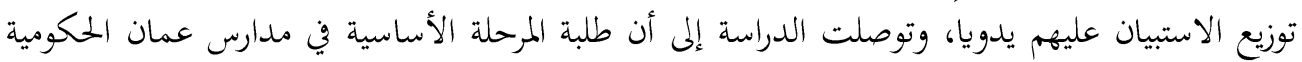

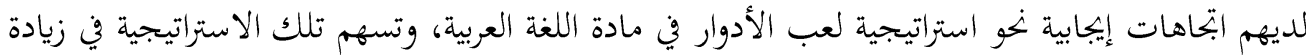

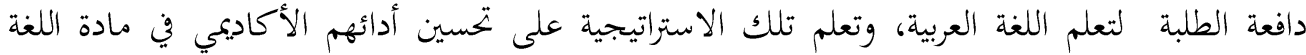

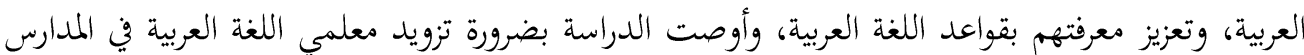
الحكومية الأساسية بدورات تدريية وورش عمل حول أساليب التدريس في اللغة العربية وكيفية توظيف

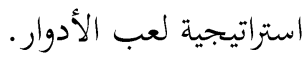
دراسة اللوزي وشحادة (2020) بعنوان: فاعلية استخدام استراتيجية العروض العملية في تحصيل طلبة الصف السادس الأساسي في مادة التربية الإسلامية في لواء ناعور.

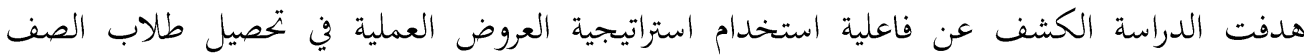

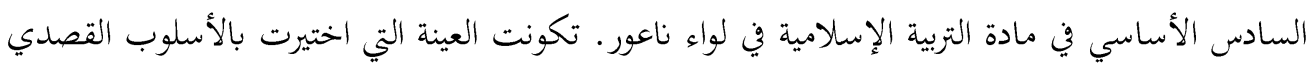

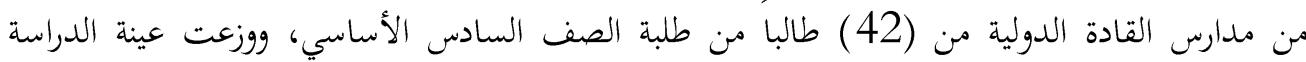

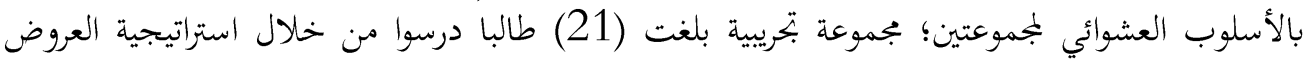

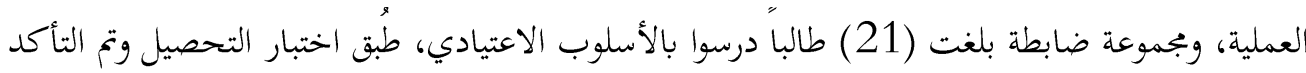

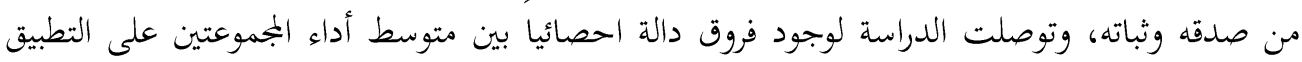

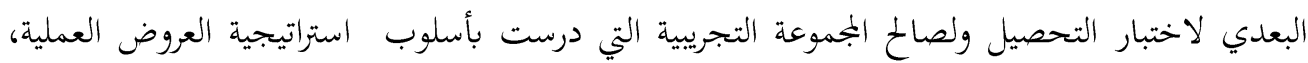
وأوصت الدراسة بتدريب معلمي التربية الإسلامية على استخدام استراتيجية العروض العمبية العملية.

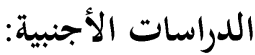

دراسة (Draissi, Yong, 2020) بعنوان: "Implementing Distance Education in Moroccan "Universities. School of Education وقد هدفت إلى معرفة خطة الاستجابة لتفشي مرض (COVID-19) وتنفيذ التعليم عن بعد في الجامعات المغربية، في هذه الدراسة قام الباحثون بفحص وثائق مختلفة تتكون من مقالات إخبارية خاصة بالصحف 
اليومية والتقارير والإشعارات من موقع الجامعات. استخدمت الدراسة منهج تحليل المتوى، وأشارت نتائج الدراسة أن الأمر المقلق هو أن جائحة COVID-19 يتحدى الجامعات لمواصلة التغلب على الصعوبات التي تواجه كل من الطلاب والأساتذة، والاستثمار في البحث العلمي وجهودها المستمرة لاكتشاف لقاح.

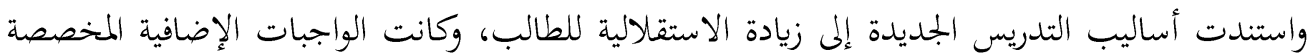

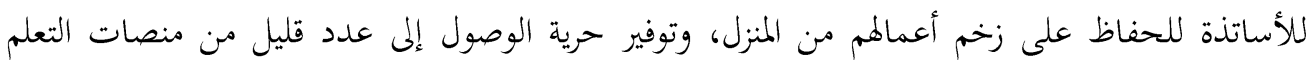
الإلكتروني المدفوعة أو قواعد بيانات.

Closure of Universities Due to Coronavirus Disease (COVID-19) " دراسة (Sahu, 2020) بعنوان

"Impact on Education and Mental Health of Students and Academic Staff والتي هدفت إلى معرفة تأثير إغلاق الجامعات بسبب فيروس كورونا (COVID-19) على التعليم والصحة العقلية للطلاب وهيئة التدريس، فقد نشأ في ووهان الصينية الفيروس التاجي الجديد (COVID-19) وقد انتشر بسرعة في جميع أنحاء العالم، وبذلك قام عدد كبير من الجامعات بتأجيل أو إلغاء جميع الأنشطة

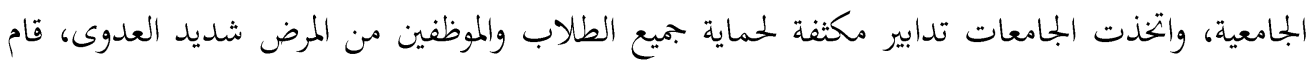
أعضاء هيئة التدريس بالانتقال إلى نظام التدريس الإلكتروني، ويسلط البحث الضوء على التأثير المتمل لانتشار COVID-19 على التعليم والصحة النفسية للطلاب، وقد أظهرت نتائج الدراسة أنه على الجامعات بلنهات تنفيذ القوانين لإبطاء انتشار الفيروس، ويجب أن يتلقى الطلاب والموظفون معلومات منتظمة من خلال

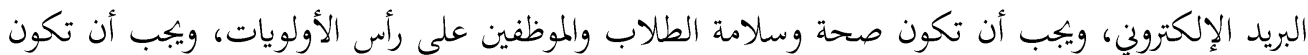

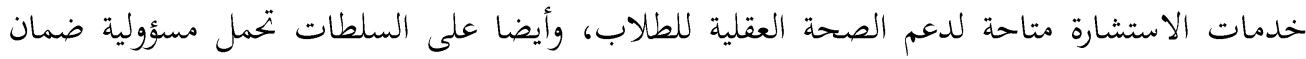

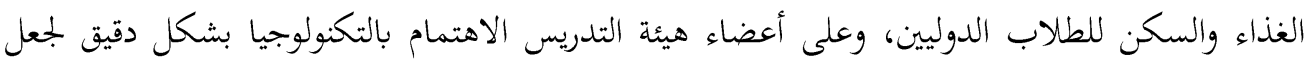
تجارب الطلبة مع التعلم غنيا وفعالًا.

مراسة (Yulia,2020) بعنوان: " Online Learning to Prevent the Spread of Pandemic Corona

"Virus in Indonesia والتي هدفت إلى توضيح طرق تأثير جائحة كورونا على إعادة تشكيل التعليم في اندونيسيا، حيث شرحت

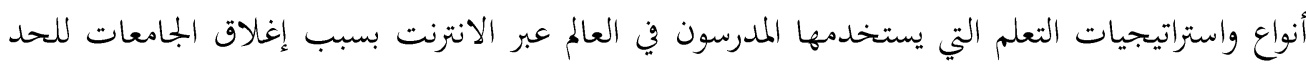
من انتشار فيروس كورونا الوبائي، كما وضحت الدراسة مزايا وفعالية استخدام التعلم من خلال الانترنت،

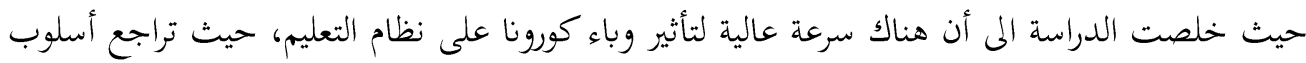
التعليم التقليدي لينتشر بدلا منه التعلم من خلال الانترنت لكونه يدعم التعلم من المنزل وبالتالي يقلل 
اختلاط الأفراد ببعضهم، ويقلل انتشار الفيروس، وأثبتت الدراسة أهمية استخدام الاستراتيجيات المختلفة لزيادة سلاسة وتحسين التعليم من خلال الانترنت.

وكذلك دراسة أجراها (Basilaia, Kvavadze, 2020) بعنوان: "Transition to Online Education in

"Schools during a SARS-CoV-2 Corona virus (COVID-19) Pandemic in Georgia هدفت إلى بتربة الانتقال من التعليم في المدراس إلى التعلم عبر الانترنت خلال انتشار وباء فيروس كورونا في جورجيا، حيث اسندت على إحصائيات الأسبوع الأول من عملية التدريس في إحدى المدارس الخاصة وبتربتها في الانتقال من التعلم وجها لوجه إلى التعليم الإلكتووني خلال جائحة كورونا، حيث قامت بمناقشة نتائج التعليم عبر الإنترنت وتم استخدام منصتي Gdu Page و Gsuite في العملية التعليمية، واستنادا المى إحصائيات الأسبوع الأول من عملية التدريس عبر الإنترنت توصل الباحثان الى أن الانتقال بين التعليم التقليدي والتعليم عبر الانترنت كان ناجحا، ويمكن الاستفادة من النظام والمهارات التي اكتسبها المعلمون والطلاب وإدارة المدرسة في فترة ما بعد الوباء في حالات مختلفة مثل ذوي الاحتياجات الخاصة الذين هم بحاجة لساعات اضافية، أو من خلال زيادة فاعلية التدريس الجماعي أو زيادة الاستقلالية لدى الطالب والخصول على مهارات جديدة. منهج الدراسة: اعتمدت الدراسة المنهج شبه التجريب، وذلك من خلال التطبيق على جموعتين بتريبية وضابطة من طلاب التعليم المهني في العراق. أفراد الدراسة: قامت الباحثة باختيار شعبتين من طلاب التعليم المهني في العراق بواقع (30) طالباً وطالبة في المجموعة التجريبية و(30) طالبا وطالبة في الجمموعة الضابطة، بحيث تم تطبيق البرنامج التعليمي على الجمبوعة التجريبية، وتم تدريس الجمموعة الضابطة بالطريقة الاعتيادية.

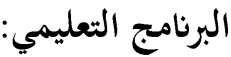
مكونات البرنامج: 1

قامت الباحثة بمراجعة الأهداف الواردة في الخطوط العريضة للمناهج والكتب المدرسية المقررة وإعادة صياغتها وتطويرها بما ينسجم مع أهداف وزارة التربية العراقية الخاصة بمنهاج اللغة العربية. 
2

قامت الباحثة بفحص محتوى المنهاج العام من حيث اتساع المعارف والمعلومات المتضمنة ومستويات

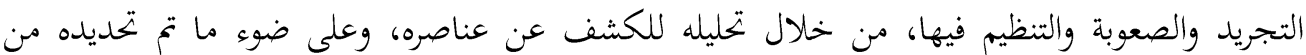
أهداف جرى تكييف المتتوى ليتلاءم مع خبرات الطلبة واهتماماتم وقدراتم.

3- الأساليب والأنثطة

تطلب تحقيق الأهداف استخدام أساليب وأنشطة متمايزة عما هو مألوف في الصف العادي في الججالات الآتية:

- - الاهتمام بالأنشطة التي تركز على التعلم الذاتي واستخدام مصادر المعرفة المتاحة في المدرسة. - مياغة أنماط متطورة من الأسئلة والمهمات المفتوحة تلؤكد على استخدام المعرفة أكثر من اكتساهـا. - - تنويع الأساليب المستخدمة في التدريس. - توفير فرص لجعل أنماط التفاعل الصفي في عدة ابتحاتات (معلم/ طالب، طالب/ معلم، طالب/

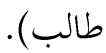
- - اتاحة الفرصة للطالب لاختيار النشاطات التي تناسب ميوله واهتماماته وقدراته. 4- التقويم - مت تم تقويم أداء الطلبة باستخدام الاختبار البعدي.

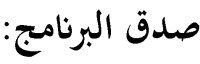
للتأكد من صدق البرنامج تم عرضه على عشرة من المحكمين من الأساتذة المتخصصين في الجامعات وعدد

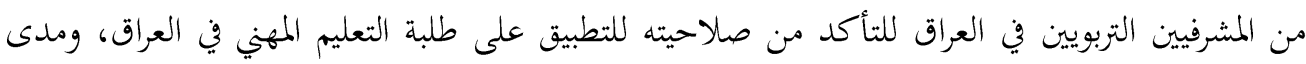
سلامة الصياغة اللغوية ومدى مناسبة البرنامج للفئة العمرية المستهدفة ومدى تضمين المهارات اللازمة في البرنامج، وتم إجراء التعديلات في ضوء ملاحظات السادة المحكمين. أداتا الدراسة: - n

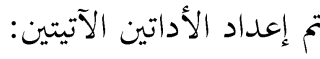
أولاً: اختبار الذكاء اللغوي: تم تحديد عدد من المواقف الخاصة في الذكاء في مادة اللغة العربية وذلك من خلال الاستفادة من الدراسات السابقة وتضمنت هذه المهارات ما يلي: - وضوح الصوت: أي أن يكون صوت الطالب واضحاً أثناء القراءة. 
- ارتباط الأفكار بعضها ببعض: وجود علاقة واضحة بين الافكار المطروحة.

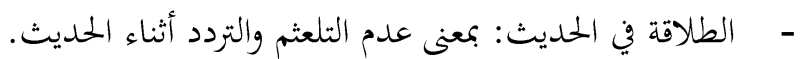
- الضبط النحوي والصريف: من خلال ضبط الكلمات والحروف أثناء التحدث. - - مهارة سلامة النطق: ويقصد بها نطق الكلمات بشكل صحيح مع مراعاة مخارج الحروف. - التحدث بسرعة مناسبة: ويقصد بها نطق الكلمات دون ابطاء أو إسراع بما يتناسب مع مع السياق. - مهارة الدقة اللغوية: ويقصد بها استخدام الألفاظ بحيث تؤدي الدلالات الصحيحة من الناحية اللغوية والمنطقية.

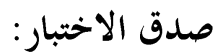

تم التأكد من صدق الاختبار بدلالة الصدق الظاهري من خلال عرضه على عشرة من المحكمين من أساتذة الجامعة وعدد من المشرفيين التربويين للحكم على مدى سلامة الصياغة اللغوية ومدى مناسبة الاختبار للفئة العمرية المستهدفة ومدى مقدرة الاختبار على قياس ما أعد من أجله، وتم إجراء التعديلات في ضوء ملاحظات السادة المحكمين.

\section{ثبات الاختبار : ت}

بعد أن تم اعتماد الاختبار بعد إجراء التعديلات التي اقترحها المحكمون ليخرج بصورته النهائية وبعد أخذ المشورة قامت الباحثة بزيارة الشعبتين التجريبية والضابطة، حيث تم إعطاء نبذة عن مضمون البرنامج، وبعدها تم تحريب الاختبار على طلبة التعليم المهني وقد تم اختيارهم وفق الآلية التي اعتمدت في اختيار العينة التجريبة والضابطة وبلغ عددهم (25) طالبا وطالبة. وقد اتصف أفراد العينة بمواصفات أفراد العينة الأصلية. واستهدفت التجربة الاستطلاعية للاختبار التحقق من الآتي:

$$
\begin{aligned}
& \text { 1 - صلاحية تعليمات الاختبار. } \\
& \text { 2- تحديد الزمن المناسب لفقرات الاختبار. } \\
& \text { 3- استخراج ثبات الاختبار. }
\end{aligned}
$$

وللتأكد من ثبات الاختبار تم تطبيقه على عينة استطلاعية من خارج عينة الدراسة وإعادة التطبيق بعد أسبوعين، ثم استخراج معامل الثبات عن طريق احتساب معامل الارتباط بيرسون بين التطبيق الأول والثاني وتم حساب معامل ارتباط بيرسون بين الاختبارين والذي بلغ (0.87) وهذا يشير الى ان تصحيح اختبار التعبير الشفهي يتمتع بدلالات ثبات مناسبة للاختبار. 
ثانيا: اختبار التحصيل:

قامت الباحثة باختيار عدد من الموضوعات باستفتاء الطلبة في مادة اللغة العربية وذلك من خلال الاستفادة من الدراسات السابقة وتتضمن المهارات: - صحة الأفكار: التأكد من أن الأفكار المطروحة صحيحة منطقياً وعلمياً.

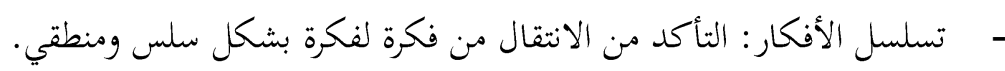
- توظيف الأدلة والشواهد: الرجوع إلى النصوص والشواهد القديمة كالآيات والأحاديث وتوظيفها في النص. - الضبط النحوي والصريف: ضبط النص من خلال ضبط أواخر حركات الكلمات ضبطاً صحيحاً تبعاً للموقع الاعرابي لكل كلمة مع صحة وسلامة الاشتقاق الصريف. - استخدام علامات الترقيم: ويقصد بها وضع علامات الترقيم في مواضعها المناسبة بما يناسب السياق في النص.

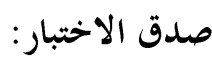

تم التأكد من صدق الاختبار بدلالة الصدق الظاهري من خلال عرضه على عشرة من المحكمين من أساتذة الجامعات وعدد من المشرفيين التربويين للحكم على مدى سلامة الصياغة اللغوية ومدى مناسبة مناسية الاختبار للفئة العمرية المستهدفة ومدى مقدرة الاختبار على قياس ما أعد من أجله، وتم إجراء التعديلات في ضوء تعديلات السادة المحكمين.

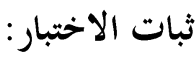
للتأكد من ثبات الاختبار تم تطبيقه على عينة استطلاعية من خارج عينة الدراسة وعددها (25) طالباً

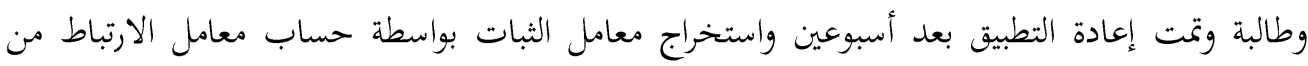
خلال معادلة بيرسون وتم حساب معامل ارتباط بيرسون بين المصححين والذي بلغ (0.87) وهذا يشير الى ان اختبار التعبير الكتابي يتمتع بدلالات ثبات مناس ملاسبة. ثبات المصححين: تم تصحيح (20) من اجابات الطلبة على اختبار التحصيل واعيد تصحيحها من مصحح آخر بناء على المعايير نفسها، وتم حساب معامل الاتفاق بين المصححين. همدف التحقق من ثبات الاختبار تطبق اختبار التحصيل على عينة مكونة من (25) طالبا وطالبة من خارج عينة الدراسة وأعيد تطبيقهما بعد مرور اسبوعين، وحسب معامل ارتباط بيرسون بين. 


\section{تصميم الدراسة:}

اتبعت الدرّاسة المنهج شبه التجريبي المتمثل في تقديم مقياس قبلي ومعالجة، واختبار بعدي في كل مهارات

EG $\quad \mathrm{O} 1 \quad \mathrm{O} 2 \quad \mathrm{XO} 1 \mathrm{O} 2$

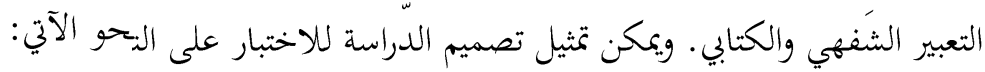

$\begin{array}{lllll}\text { CG } & \text { O1 } & \text { O2 } & \text { O1 } & \text { O2 }\end{array}$

EG

CG

O1

O2 - O2 اختبار بعدي.

X

- - منهج اعتيادي.

المعالجة الإحصائية:

تم استخدام المعالجات الإحصائية الآتية:

1- التكرارات والنسب المئوية لوصف أفراد الدراسة بالنسبة لمتغير الدراسة.

2- المتوسط الحسابي وذلك لحساب القيمة لأفراد الدراسة لكل عبارة أو مجموعة من العبارات (المحاور)، والمتوسط الحسابي العام لكل محور، وذلك للإجابة عن التساؤلات. 3- اختبار (ت) للمقارنة بين متوسطات استجابات أفراد الدراسة 4- معامل ارتباط بيرسون.

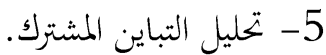

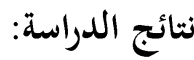

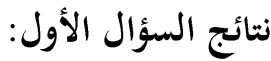
لا توجد فروق ذات دلالة إحصائية عند مستوى دلالة (0.05 التجريبية ومتوسط علامات أفراد المجموعة الضابطة على الاختبار البعدي للتحصيل تعزى للطريقة (البرنامج التعليمي/ الاعتيادية) والجنس والتفاعل بينهما. لفحص هذه الفرضية تم حساب المتوسطات الحسابية والانحرافات المعيارية لعلامات الطلبة وإجراء تحليل التباين الثنائي (Two Way ANOVA)، والجدول رقم (1) يوضح قيم المتوسطات الحسابية والانحرافات المعيارية للدرجة الكلية لاختبار القراءة لمجموعات الدراسة على القياسين القبلي والبعدي. 
جدول (1) المتوسطات الحسابية والاخرافات المعيارية للدرجات التحصيل لمجموعات الدراسة على القياسين القبلي والبعدي

\begin{tabular}{|c|c|c|c|c|c|c|}
\hline \multicolumn{3}{|c|}{ القياس البعدي } & \multicolumn{3}{|c|}{ القياس القبلي } & \multirow[b]{2}{*}{ الجموعة } \\
\hline الانحراف & المتوسط المسابي & العدد & الانحراف & المتوسط الحسابي & العدد & \\
\hline 6.41 & 26.04 & 50 & 4.83 & 26.48 & 30 & الضابطة \\
\hline 3.91 & 35.80 & 25 & 8.14 & 28.04 & 15 & تجريبية أولى \\
\hline 3.49 & 36.44 & 25 & 4.84 & 30.56 & 15 & تجريية ثانية \\
\hline
\end{tabular}

تشير المتوسطات الحسابية لاختبارات القراءة القبلية والبعدية أن هناك فروقا ظاهرية بين درجات المجموعتين

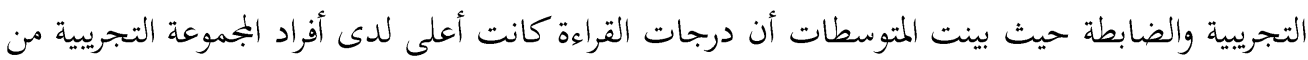

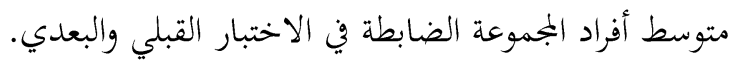

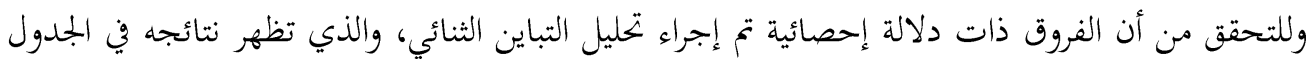
رقم (2). جدول (2) تحليل التباين الثنائي لدرجات على الاختبار القرائي لمجموعات الدراسة التجريبيتين والمجموعة الضابطة على القياس البعدي تبعا لمتغير الجنس

\begin{tabular}{|c|c|c|c|c|c|}
\hline مستوى & قيمة "ف" & متوسط المربعات & درجات الحرية & ججموع المربعات & سدر التباين \\
\hline 0.00 & 54.30 & 1370.92 & 2 & 2741.83 & موعة \\
\hline 0.23 & 1.43 & 36.08 & 1 & 36.08 & \\
\hline \multirow[t]{3}{*}{0.06} & 2.98 & 75.15 & 2 & 150.31 & موعة * الجنس \\
\hline & & 25.25 & 24 & 2373.26 & \\
\hline & & & 29 & 5301.48 & موع \\
\hline
\end{tabular}

يتضح من الجدول رقم (2) أن قيمة (ف) بلغت (54.30) وهذه قيمة دالة إحصائيا عند مستوى الدلالة (0.05 (0) وهذا يعني أن البرنامج التعليمي المقترح كان له أثر في تنمية التحصيل الدراسي لدى أفراد

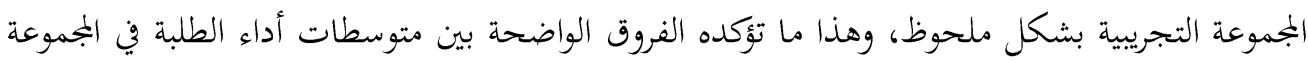
التجريبة والمجموعة الضابطة لصالح الجموعتين التجريبيتي، حيث بلغ المتوسط الحسابي للمجموعتين 
التجريبيتين (الاستقصاء) (36.44)، العصف الذهني (35.80) فيما بلغ المتوسط الحسابي للمجموعة الضابطة (26.04) كما تظهره المتوسطات الحسابية في جدول رقم (3).

جدول (3) نتائج اختبار (LSD) للمقارنات البعدية بين مجموعات الدراسة على اختبار التحصيل

\begin{tabular}{|c|c|c|c|}
\hline تجريبية ثانية الاستقصاء & تجريبية أولى العصف الذهني & الضابطة & \\
\hline $9.374-^{*}-$ & $9.368{ }^{-*}-$ & & الضابطة \\
\hline $.007-$ & & & تجريبية أولى \\
\hline & & & تحريبية ثانية \\
\hline
\end{tabular}

"الفروق دالة عند مستوى 0.05 فأقل.

يتضح من الجدول رقم (3) بأن الفروق الدالة كانت بين الجمموعة التجريبية الأولى والمجموعة الضابطة والتي

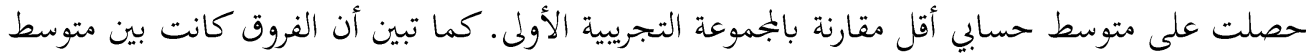
المجموعة التجريبة الثانية والمجموعة الضابطة حيث كانت الفروق لصالح أفراد المجموعة التجريبية الثانية. ولم لمانم يظهر هناك فروق دالة بين المجموعتين التجريبيتين. توجد فروق ذات دلالة إحصائية عند مستوى (م=0.05) للعلامة الكلية لدى طلاب التعليم المهني في

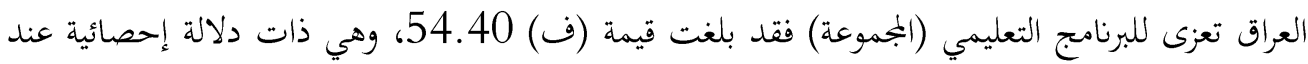

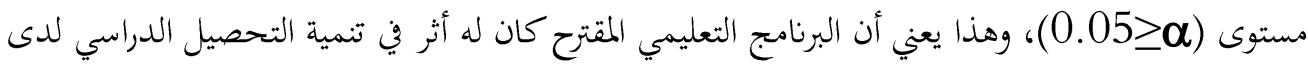
أفراد المجموعة التجريبة بشكل ملحوظ، وهذا ما تؤكده الفروق الواضحة بين متوسطات أداء الطلبة في الجمموعة التجريبية والمجموعة الضابطة لصالح الجموعة التجريبية حيث بلغ المتوسط الحسابي للمجموعة التجريبية الأولى (35.80) والمتوسط الحسابي للمجموعة التجريبية الثانية (36.44) في حين بلغ المتوسط الحسابي للمجموعة الضابطة (26.04) جدول (3).

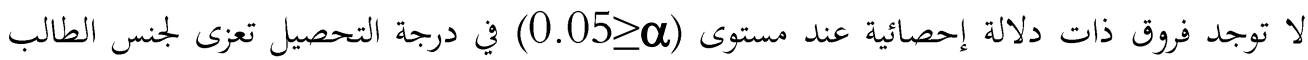
حيث بلغت قيمة (ف) (1.43) وهي غير دالة إحصائيا.

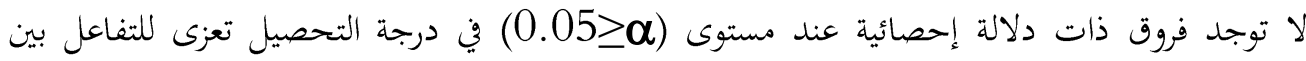
المجموعة وجنس الطالب حيث بلغت قيمة (ف) (2.98) وهي غير دالة إحصائيا. 
جدول (4) المتوسطات الحسابية والانحرافات المعيارية لدرجات المهارات التحصيل لمجموعات الدراسة البعدي تبعا لمتغيري المجموعة الجنس والتفاعل بينهما

\begin{tabular}{|c|c|c|c|c|c|c|}
\hline \multicolumn{3}{|c|}{ إناث } & \multicolumn{3}{|c|}{ ذكور } & \multirow[b]{2}{*}{ البجموعة } \\
\hline الالمعياري & المتوسط الحسابي & العدد & الانحراف & المتوسط الحسابي & العدد & \\
\hline 5.38 & 27.72 & 29 & 6.78 & 23.33 & 21 & الضابطة \\
\hline 4.11 & 36.25 & 12 & 3.82 & 35.38 & 13 & تجريبية أولى \\
\hline 3.64 & 35.64 & 11 & 3.36 & 37.07 & 14 & تجريبية ثانية \\
\hline 6.27 & 31.37 & 52 & 8.30 & 30.60 & 48 & الجمموع \\
\hline
\end{tabular}

تشير النتائج المبينة في الجمدول رقم (4) إلى أن هناك اختلافات ظاهرية في درجات القراءة على الاختبار البعدي لأفراد الجمموعتين التجريبية والجموعة الضابطة تبعا لمتغير الجنس والتفاعل بينهما. يتضح من الجدول رقم (4) أن قيمة (ف) لمتغير الجنس بلغت (1.43) وهذه قيمة ليست دالة إحصائيا عند مستوى الدلالة (0.05 0 (0)، لذا نقبل الفرض الصفري الذي ينص على: " لا توجد فروق ذات دلالة إحصائية عند مستوى دلالة (0.05 تعزى للجنس. كذلك فان جدول (4) يشير إلى أن قيمة (ف) لتفاعل متغيري البرنامج والجنس بلغت (2.98) وهذه قيمة ليست دالة إحصائيا عند مستوى الدلالة (0) 05 (0)، لذا نقبل الفرض الصفري الذي ينص على: "لا يوجد تفاعل دال إحصائيا عند مستوى الدلالة (0.05 التحصيل. السؤال الثاين: لا توجد فروق ذات دلالة إحصائية عند مستوى دلالة (0.05 $)$ بين متوسط علامات أفراد الجمموعة التجريبية ومتوسط علامات أفراد الجمموعة الضابطة على الاختبار البعدي للذكاء اللغوي تعزى للطريقة (البرنامج التعليمي/الاعتيادية) والجنس والتفاعل بينهما لفحص هذه الفرضية تم حساب المتوسطات الحسابية والانحرافات المعيارية وإجراء تحليل التباين الثنائي (Two Way ANOVA) الكلية لاختبار الذكاء اللغوي لمجموعات الدراسة على القياسين القبلي والبعدي. 


\begin{tabular}{|c|c|c|c|c|c|c|}
\hline \multicolumn{3}{|c|}{ القياس البعدي } & \multicolumn{3}{|c|}{ القياس القبلي } & \multirow[b]{2}{*}{ الجموعة } \\
\hline الالمعراف & المستوسط & العدد & الانمراف & المتوسط & العدد & \\
\hline 6.32 & 26.74 & 50 & 6.44 & 27.52 & 30 & الضابطة \\
\hline 3.18 & 35.20 & 25 & 8.00 & 27.84 & 15 & تجرييية أولى \\
\hline 3.47 & 32.44 & 25 & 4.55 & 24.48 & 15 & تجرييية ثانية \\
\hline
\end{tabular}

تشير المتوسطات الحسابية لاختبار الذكاء اللغوي القبلية والبعدية أن هناك فروقا ظاهرية بين درجات المجموعتين التجريبية والضابطة حيث بينت المتوسطات أن درجات الذكاء اللغوي كانت أعلى لدى أفراد المجموعة التجريبية من متوسط أفراد المجموعة الضابطة في الاختبار القبلي والبعدي. وللتحقق من أن الفروق ذات دلالة إحصائية تم إجراء تحليل التباين الثنائي (Two way ANOVA)، والذي مئي تظهر نتائجه في الجدول رقم (6).

جدول (6) تحليل التباين الثنائي لدرجات على اختبار الذكاء اللغوي لبجموعات الدراسة التجريبيتين والمجموعة الضابطة على القياس

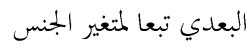

\begin{tabular}{|c|c|c|c|c|c|}
\hline مستوى & قيمة "ف" & متوسط المربعات & درجات الحرية & مجموع المربعات & مصدر التباين \\
\hline 0.00 & 33.60 & 751.18 & 2 & 1502.36 & المجموعة \\
\hline 0.01 & 7.09 & 158.45 & 1 & 158.45 & \\
\hline \multirow[t]{3}{*}{0.09} & 2.43 & 54.28 & 2 & 108.55 & موعة * الجنس \\
\hline & & 22.35 & 44 & 2101.667 & لخطأ \\
\hline & & & 49 & 3871.03 & \\
\hline
\end{tabular}

يتضح من الجدول رقم (6) أن قيمة (ف) كانت (33.60) وهذه قيمة دالة إحصائياً عند مستوى الدلالة

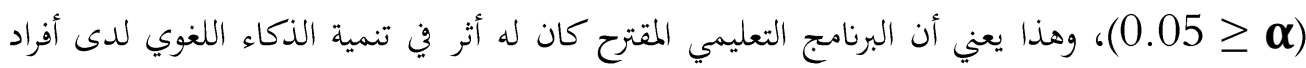
المجموعة التجريبية بشكل ملحوظ، وهذا ما تؤكده الفروق الواضحة بين متوسطات أداء الطلبة في المجموعة التجريبية والجموعة الضابطة لصالح الجموعتين التجريبيتن، حيث بلغ المتوسط الحسابي للمجموعتين التجريبيتين (الاستقصاء) (32.44)، العصف الذهني (35.20) فيما بلغ المتوسط الحسابي للمجموعة الضابطة (26.74) كما تظهره المتوسطات الحسابية في جدول رقم (7)، ولتحديد بين أي من المتوسطات 
تقع الفروقات الدالة تم إجراء اختبار (الفروق الأقل دلالة LSD) للمقارنات البعدية، والذي تظهر نتائجه في

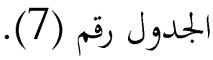

توجد فروق ذات دلالة إحصائية عند مستوى (م=0.05) للعلامة الكلية للذكاء اللغوي تعزى للبرنامج التعليمي (الجمموعة) فقد بلغت قيمة (ف) 33.60، وهي ذات ذات دلالة إحصائية عند مستوى

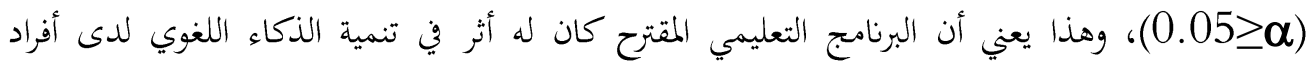
المجموعة التجريبة بشكل ملحوظ، وهذا ما تؤكده الفروق الواضحة بين متوسطات أداء الطلبة في المجموعة المهاء التجريبية والمجموعة الضابطة لصالح المجموعة التجريبية حيث بلغ المتوسط الحسابي للمجموعة التجريبية الأولى (35.20) والمتوسط الحسابي للمجموعة التجريبية الثانية (32.44) في حين بلغ بلغ المتوسط المبطية الحسابي للمجموعة الضابطة (26.74) جدول (8).

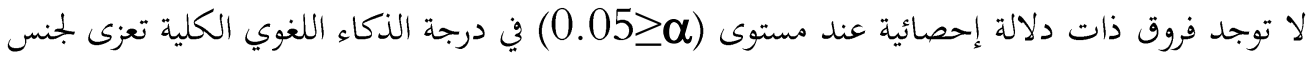
الطالب حيث بلغت قيمة (ف) (7.09) وهي غير دالة إحصائيا. لا توجد فروق ذات دلالة إحصائية عند مستوى (0.05 (0) في درجة الذكاء اللغوي الكلية تعزى للتفاعل بين المجموعة وجنس الطالب حيث بلغت قيمة (ف) (2.93) وهي غير دالة إحصائيا.

\begin{tabular}{|c|c|c|c|}
\hline تجرييية ثانية الاستقصاء الذكاء اللغوي & تجرييية أولى العصف الذهني & الضابطة & \\
\hline $5.7-"$ & $8.46^{*}$ & & الضابطة \\
\hline \multirow[t]{2}{*}{2.225} & & & تجرييية أولى \\
\hline & & & تجرييية ثانية \\
\hline
\end{tabular}

يتضح من الجدول رقم (7) بأن الفروق الدالة كانت بين الجمموعة التجريبية الأولى والمجموعة الضابطة والتي

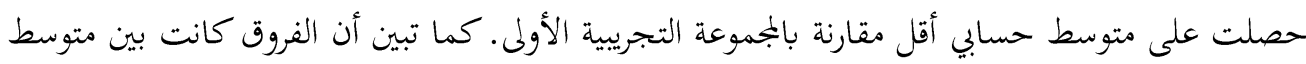
المجموعة التجريبة الثانية والمجموعة الضابطة حيث كانت الفروق لصالح أفراد المجموعة التجريبية الثانية. 


\begin{tabular}{|c|c|c|c|c|c|c|}
\hline \multicolumn{3}{|r|}{ إناث } & \multicolumn{3}{|r|}{ ذكور } & \multirow[b]{2}{*}{ الججموعة } \\
\hline الانمراف & المتوسط & العدد & الانغراو & المتوسط & العدد & \\
\hline 4.91 & 29.03 & 29 & 6.77 & 23.57 & 21 & الضابطة \\
\hline 3.17 & 35.75 & 12 & 3.22 & 34.69 & 13 & تجريبية أولى \\
\hline 3.04 & 33.27 & 11 & 3.75 & 31.79 & 14 & تجريبية ثانية \\
\hline 5.06 & 31.48 & 52 & 7.11 & 28.98 & 48 & الججموع \\
\hline
\end{tabular}

تشير النتائج المبينة في الجدول رقم (8) إلى أن هناك اختلافات ظاهرية في درجات الذكاء اللغوي على

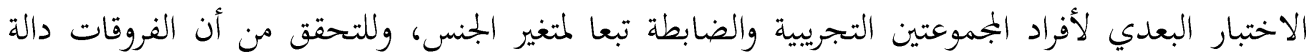
إحصائيا تم إجراء تحليل التباين الثنائي، والذي تظهر نتائجه في الجدول رقمر (9)

جدول (9) تحليل التباين الثنائي لدرجات على اختبار الذكاء اللغوي بلموعات الدراسة التجريبين والمجموعة الضابطة على القياس البعدي تبعا لمتغير الجنس

\begin{tabular}{|c|c|c|c|c|c|}
\hline مستوى الدلالة & قيمة "ف" & متوسط المربعات & درجات الحرية & مجموع المربعات & صدر التباين \\
\hline 0.00 & 33.66 & 751.16 & 2 & 1502.38 & \\
\hline 0.01 & 7.09 & 158.44 & 1 & 158.43 & \\
\hline \multirow[t]{3}{*}{0.09} & 2.45 & 54.27 & 2 & 108.53 & وعة * الجنس \\
\hline & & 22.34 & 43 & 2101.669 & \\
\hline & & & 48 & 3871.03 & \\
\hline
\end{tabular}

ويتضح من الجدول رقم (9) أن قيمة (ف) لمتغير الجنس بلغت (7.09) وهذه قيمة دالة إحصائياً عند

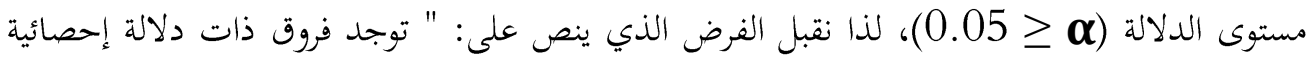

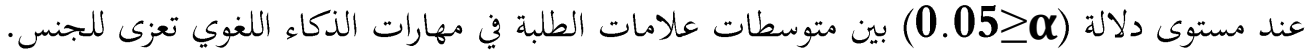
وبمراجعة المتوسطات الحسابية تبين أن المتوسط الحسابي للإناث أعلى منه مقارنة بالذكور. 


\section{مناقشة النتيجة المتعلقة بالسؤال الأول:}

لا توجد فروق ذات دلالة إحصائية عند مستوى دلالة (0.05 $)$ بين متوسط علامات أفراد المجموعة التجريبة ومتوسط علامات أفراد المجموعة الضابطة على الاختبار البعدي للتحصيل تعزى للطريقة (البرنامج التعليمي/ الاعتيادية) والجنس والتفاعل بينهما. بعد التحليل الإحصائي للبيانات رفضت الفرضية الصفرية الأولى، وتم قبول الفرضية البديلة، وعليه يمكن القول بأن استراتيجيتي التدريس أكثر نفعا و تأثيرا في تنمية التحصيل مقارنة مع الطريقة الاعتيادية. وهذه التهايه النتيجة تتوافق مع ما توصلت إليه دراسة كل من درويش (2007) والدوسري (2005) في تأكيدها

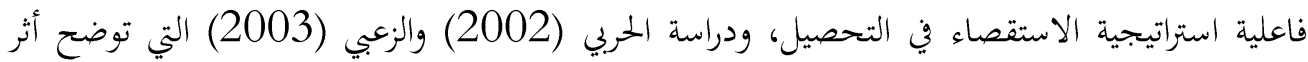

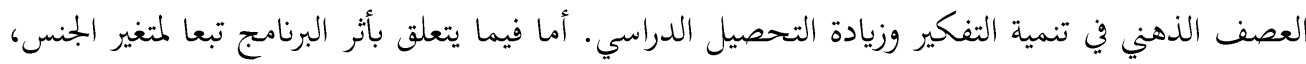
فقد ظهرت النتائج عدم وجود فروق ذات دلالة إحصائية عند مستوى الدلالة (0.05 (0.0) بين متوسطات طلبة المجموعة التجريبية (الذكور والإناث) على اختبار القراءة، وهذا يعني أن البرنامج التعليمي قد حسن تحصيل كل من (الذكور والإناث) بالمقارنة مع تحصيل طلبة المجموعة الضابطة (الذكور والإناث) ممن تعلموا بالطريقة الاعتيادية مهارات التحصيل.

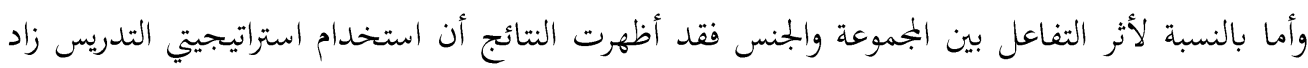

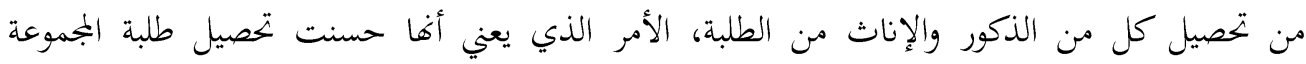
التجريبة ذكورا وإناثا بالمقارنة مع تحصيل طلبة المجموعة الضابطة (الذكور والإناث) ممن تعلموا بالطريقة

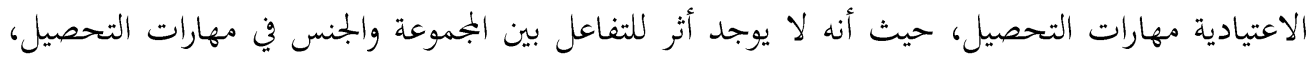

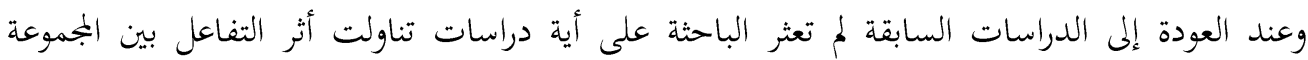
(البرنامج) والجنس في مهارات التحصيل، لذا لم يكن بالإمكان مقارنة نتيجة هذه الدراسة مع نتائج دراسات أخرى.

مناقشة النتيجة المتعلقة بالسؤال الثاني: لا توجد فروق ذات دلالة إحصائية عند مستوى دلالة (0.05 $)$ بين متوسط علامات أفراد الجمموعة التجريبية ومتوسط علامات أفراد المجموعة الضابطة على الاختبار البعدي للذكاء اللغوي تعزى للطريقة

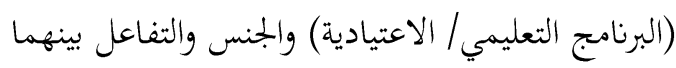

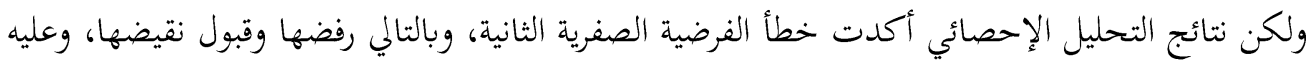
يمكن القول إن استراتيجيتي التدريس أكثر نفعا وتأثيرا في تنمية مهارات الذكاء اللغوي مقارنة مع الطريقة 
الاعتيادية. وهذه النتيجة تتوافق مع ما توصلت إليه دراسة كل من درويش (2007) التي تناولت أثر استراتيجيتي الاستقصاء الحر والاستقصاء الموجه في تنمية مهارات التعبير الشفوي، ودراسة الدوسري (2005) والتي أثبتت أثر الاستقصاء في تنمية التفكير الناقد، ودراسة الهزايمة (2004) التي أكدت على على إنى أن استراتيجية الاستقصاء الموجه ساعدت الطالبات على الاحتفاظ بالمعلومات بعد فهمها، ودراسة السالمي

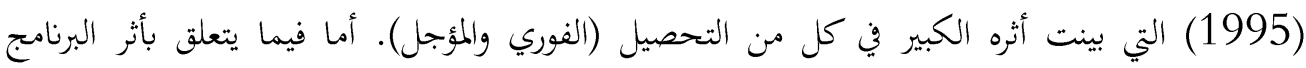
التعليمي باختلاف جنس الطالب، فقد أظهرت النتائج وجود فروق ذات دلالة إحصائية عند مستوى

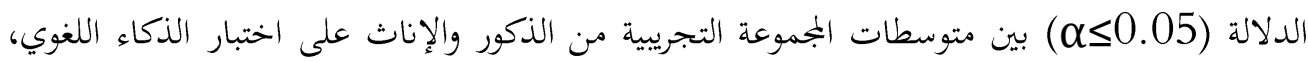

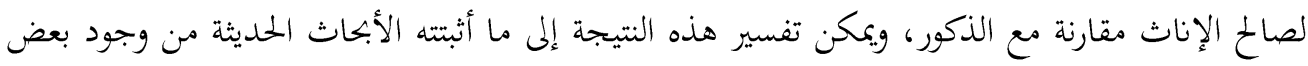
الفروقات بين أدمغة الذكور والإناث من حيث السيطرة الدماغية لكلا نصفي الدماغ، حيث يتميز الذكور في القدرات الفراغية والمكانية والاستنتاج الرياضي، بينما تتميز الإناث في الطلاقة اللفظية والمهارات الحركية

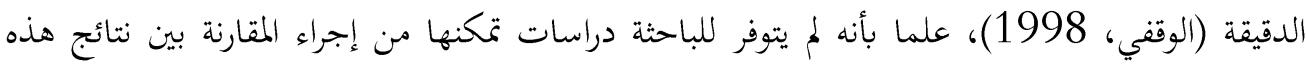

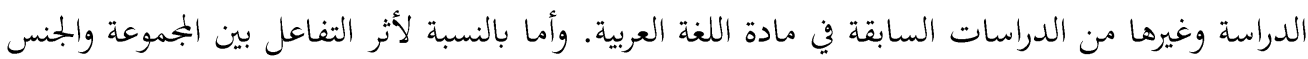
فقد أظهرت النتائج أن الاستخدام استراتيجيتي زاد من تحصيل طلبة المجموعة التجريبية (ذكورا وإناثا) بالمقارنة مع تحصيل طلبة المجموعة الضابطة (الذكور والإناث) ممن تعلموا بالطريقة الاعتيادية مهارات الذكاء اللغوي، حيث وجد أنه لا يوجد أثر للتفاعل بين المجموعة والجنس في مهارات الكتابة وعند العودة إلى ولى الدراسات السابقة لم تعثر الباحثة على أية دراسة تناولت أثر التفاعل بين المجموعة (البرنامج) والجنس في تهني تدريس الكتابة. لذا لم يكن بالإمكان مقارنة نتيجة هذه الدراسة مع نتائج أخرى.

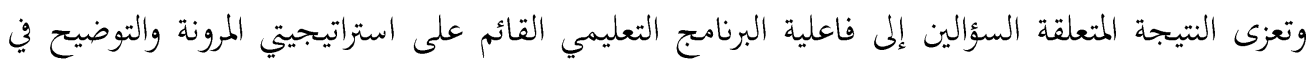
تدريس التحصيل والذكاء اللغوي، وربما يعود ذلك إلى كون طريقة الاستقصاء طريقة تسهم بشكل كبير في رفد الطلبة بالمعلومات اللازمة لمناقشة الموضوعات المطروحة، بالإضافة إلى دعم مخزون الطلبة من الألفاظ

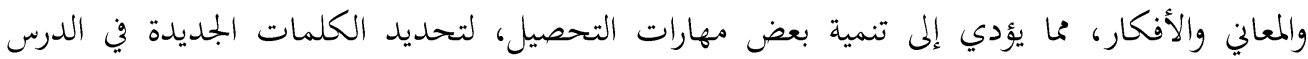
وتحديد الكلمات التي تنتهي بنون أو تنوين وتعيين همزة الوصل وهمزة القطع، هذا وفضلا عن كوها وسيلة متميزة تعمل على تطوير قدرات التفكير لدى الطلبة من خلال إعادة تنظيم المعرفة، وتوليد الأفكار واختبارها واستنتاجها على مواقف جديدة، ويقرر عنبر (1991) أن طريقة الاستقصاء طريقة تضع المتعلم في موقف تعلمي محير ومشكك، يثير انتباهه ويدفعه إلى البحث عن المعلومة الجلديدة. وإلى ما تتميز به طريقة الاستقصاء من تغير في الرتابة التي اتسمت بها طرائق التدريس الاعتيادية حيث يتطلب الاستقصاء 
خروجا عن النمط التقليدي القائم على الإلقاء وتخزين المعلومات في ذاكرة الطلبة، فالأمر بات مختلفا؛ فالطلبة يسعون بأنفسهم وراء المعرفة، ويوازنون بينها وبين غيرها من المعلومات المتوافرة، مما يجعلهم يتعلمون

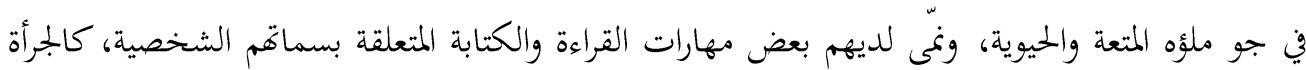
والثقة بالنفس، والمناقشة الرأي. وكذلك قدرة الاستقصاء على تلبية حاجات الطلبة ورغباةم المتمثلة في البحث والاكتشاف، والمتعة في

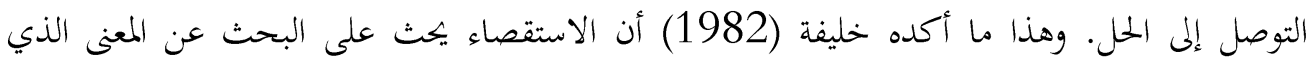
يتطلب من الشخص القيام بالعمليات العقلية لفهم الخبرة التي يمر بها. بالإضافة إلى أن الاستقصاء فيه

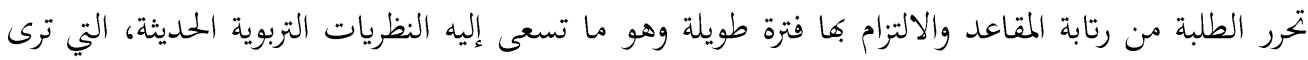

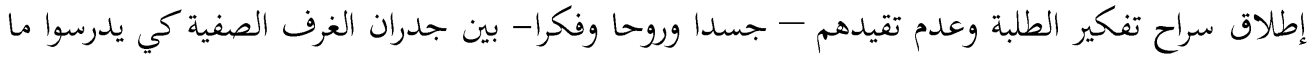
شاؤوا، وفي الوقت الذي يريدون. هذا فضلا عن شعور الطلبة بالمسؤلية، عند تعلمهم من خلال الاستقصاء حيث يسلكون سلوك العلماء، وينتجوا المعرفة بعد أن كانوا مستقبلون لها فقط، وهذا ما أكده الحيلة

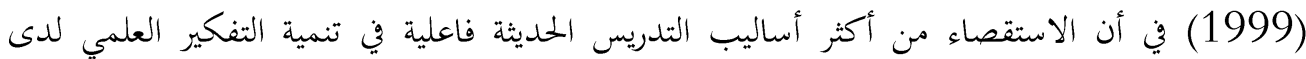
الطلبة، حيث إنه يتيح الفرصة أمام الطلبة لممارسة طرق التعليم وعملياته، وهنا يسلك المتعلم سلوك العالم الصغير في بحثه، وتوصله إلى النتائج.

التوصيات:

بناء على ما لخصت إليه الدراسة الحالية من نتائج، فإنّ الباحثة توصي بالآتي:

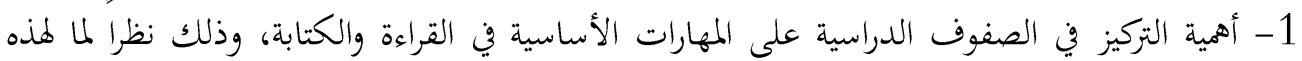
المهارات من دور كبير في اكساهم المهارات الضرورية التي تساعدهم مستقبلا في اتقان مهارتي القراءة والكتابة. 2- تركيز مناهج اللغة العربية -وتحديدا المرحلة الأساسية الدنيا- على مهارات الاستقصاء والعصف الذهني، وتضمين دليل المعلم بعض النماذج لخطط دراسية تنفذ من خلال الاستقصاء وأخرى من لرن خلال العصف الذهني. 3- إجراء دراسات مماثلة للدراسات الحالية على صفوف أخرى، وعلى مهارات أخرى في اللغة العربية، غير مهارات القراءة والكتابة.

4- العمل على تدريب معلمي اللغة العربية على توظيف الاستراتيجيات التدريسية الحديثة ومنها

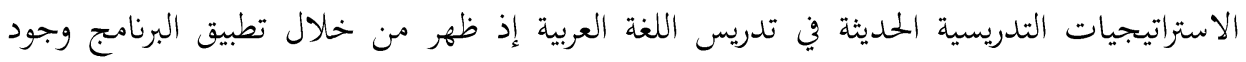


ضعف في استيعاب بعض مهارات التعبير الشفهي والكتابي كمهارة الضبط النحوي والصريف أثناء

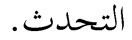

5- إثراء المناهج الدراسية بالعديد من الاستراتيجيات التدريسية الحديثة بما يؤدي إلى تحسين مهارات الطلبة في العديد من مهارات اللغة العربية كمهارتي التعبير الشفهي والتعبير الكتابي.

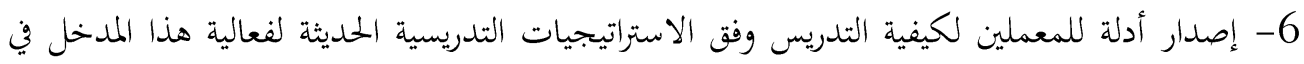
زيادة فرص التعلم لدى الطلبة. 7- توجيه خخططي المناهج ومؤلفي الكتب المدرسية لتبني الاستراتيجيات التدريسية الحديثة في تصميم

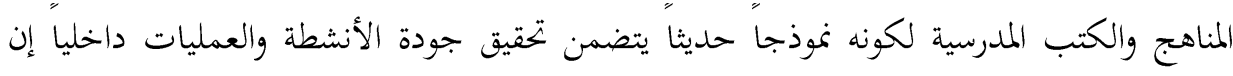

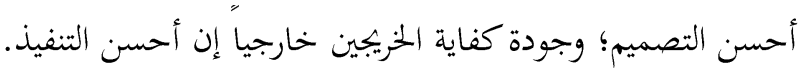
8- إعداد برامج خاصة لتدريس اللغة العربية للطلبة الموهوبين والمتفوقين مبنية على نماذج متخصصة في تدريس هذه الفئة للطلبة إذ تفتقر معظم غرف المصادر في مدارس وزارة التربية العراقية لمثل هذه

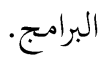

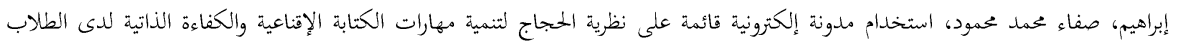

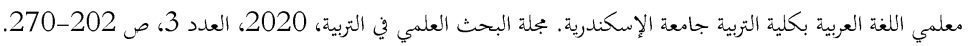

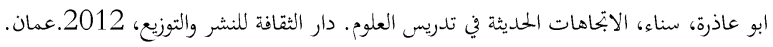
2 3. اسماعيل، بليغ، استراتيجيات تدريس اللغة العربية، أطر نظرية وتطبيقات عملية. دار المناهج للنشر والتوزيع، 2013، 2013، عمان.

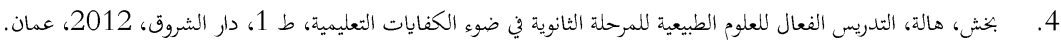
الثبيتي، يسرى، واقع استخدام معلمات اللغة العربية في مرحلة التعليم الثانوي في مدينة الطائف لاستراتيجيات التعلم النشط، مجلة الدراسات التربوية .5

والنفسية،2020، العدد 2، ص 270-288. 6 6. جابر، جابر عب الحميد، الذكاءات المتعددة والفهم: تنمية وتعميق. دار الفكر العربي، 2019، مصر.

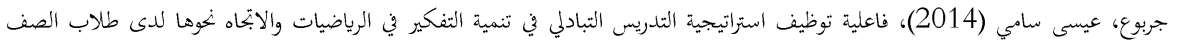
.7 الثامن الأساسي بغزة، رسالة ماجستير غير منشورة، الجامعة الإسلامية، غزة، فلسطين.

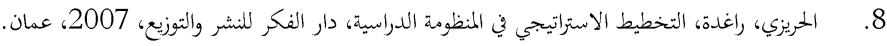
حسن، رمضان علي، أثر برنامج تدريبي قائم على عمل الدماغ في تنمية المرونة المعرفية لدى تلاميذ الحلقة الثانية من التعليم الأساسي، مجلة .9

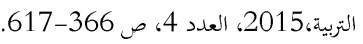
الزبون، احمد، أثر استراتيجية الصف المقلوب في تحسين مستوى الدافعية والتحصيل الدراسي لدى التلاميذ بطيئي التعلم في الرياضيات، دراسات،

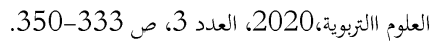

الزبون، عيسى سعد، ابتاهات طلبة المرحلة الأساسية في المدارس المكومية في عمان نحو استراتيجية لعب الأدوار في مادة اللغة العببية، مجلة الفنون

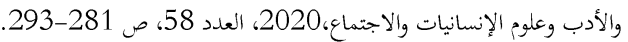
سلمان، سلوى جرجيس وعلوان، طلال غالب، أثر استعمال استراتيجية سوم في تحصيل مادة قواعد اللغة العربية لدى طلبة قسم التربية الخاصة، المُلة .12

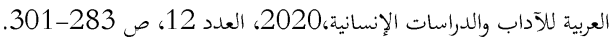


13. سليمان، علي محمد، استراتيجية الصف المقلوب وتنمية المهارات التدريسية وتوكيد الذات لمهنية لدى الطلاب للعلمين: دراسة بجريبية، مجلة كلية

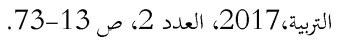

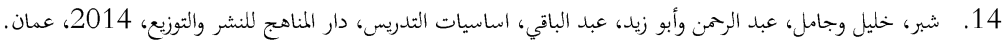

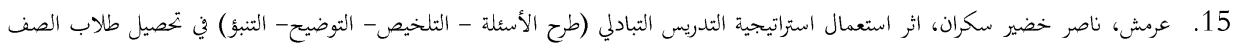

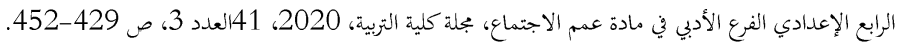

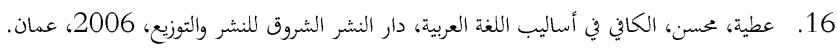

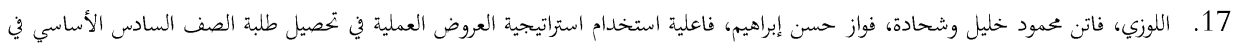

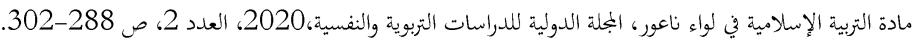

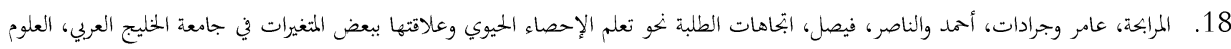

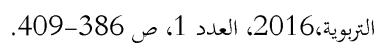

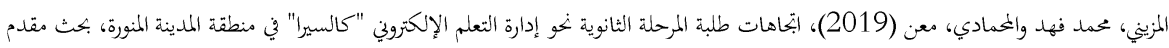

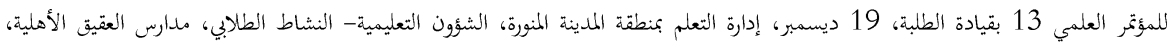
المملكة العربية السعودية، الرياض. 20. المصاروة، ربيع ثلجي عيادة (2015)، الذكاءات المتعددة (اللغوي والمنطقي) وعلاقتها بالتحصيل لدى طلبة الصف الثامن في مادئ اللغة العربية والرياضيات، رسالة ماجستير غير منشورة، جامعة مؤتة، الكرك. لمادك.

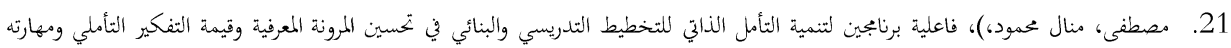

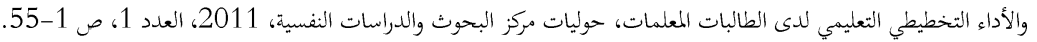

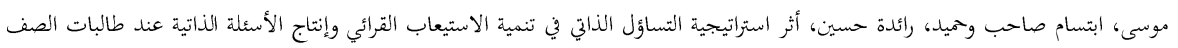

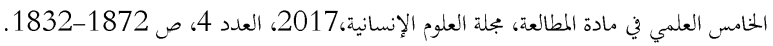

